\title{
Architekt Jakub Fontana w stużbie marszałka Franciszka Bielińskiego
}

$\mathrm{W}$ prawdzie postać Jakuba Fontany (1710-1773) jest doskonale znana dzięki monografii Aldony Bartczakowej oraz licznym publikacjom innych badaczy ${ }^{1}$, nowo znalezione źródła archiwalne pozwalają jednak na znaczące uzupełnienie dotychczasowej wiedzy na temat tego wybitnego architekta warszawskiego, zwłaszcza odnośnie do zakresu i charakteru prac dla jego głównego protektora, jakim był związany silnie z Warszawą czasów saskich Franciszek Bieliński (1683-1766) - cześnik koronny (od 1713), wojewoda chełmiński (od 1725), w końcu marszałek nadworny (od 1732) i wielki koronny (od 1742) $)^{2}$. Niniejszy artykuł zawdzięcza swe powstanie odnalezieniu nieznanych dotąd, ocalałych fragmentów rodowego archiwum Bielińskiego, znajdujących się w zasobach Archiwum Państwowego w Bydgoszczy i Archiwum Państwowego w Kielcach, oraz poszerzonej kwerendzie w Archiwum Głównym Akt Dawnych, a także w Archiwum Prowincji Bernardynów w Krakowie.

Początki znajomości Jakuba Fontany z Bielińskim, ówczesnym wojewodą chełmińskim, a wkrótce marszałkiem nadwornym, datują się na pierwszą połowę lat 30 . XVIII w. $\mathrm{Z}$ całą pewnością pierwsze kontakty z rodziną Bielińskich nawiązał jeszcze w początku lat 20. ojciec architekta, budowniczy warszawski Giuseppe Giacomo (Józef) Fontana (1676-1739), od 1715 r. zamieszkały na stałe w stolicy, co najmniej od 1738 r. szczycący się tytułem „Architekta Jego Królewskiej Mości” (Architectus Sacri Regni Maiestatis) ${ }^{3}$.

\footnotetext{
${ }^{1}$ Z ważniejszych publikacji należy wymienić: Zbigniew REWSKI, „Fontana Jakub (1710-1773)”, [w:] Polski stownik biograficzny (dalej: PSB), t. VII, Kraków 1948-1958, s. 54-55; Aldona BARTCZAKOWA, Jakub Fontana. Architekt warszawski XVIII wieku, Warszawa 1970; Wojciech BOBERSKI, „Fontana (Fontanna, Fontani) Jakub (Giacomo)”, [w:] Allgemeines Künstlerlexicon. Die Bildenden Künstler aller Zeiten und Völker, t. 27, München-Leipzig 2004, s. 124-126; Monika WYSZOMIRSKA, „Fontana (Fontanna, Fontani) Jakub (Giacomo) (1710-1773)”, [w:] Stownik architektów i budowniczych środowiska warszawskiego XV-XVIII w., red. Paweł MIGASIEWICZ, Hanna OSIECKASAMSONOWICZ, Jakub SITO, Warszawa 2016, s. 137-150 (tamże zebrana kompletna literatura).

${ }^{2}$ Marszałek Franciszek Bieliński nie ma pełnej naukowej biografii. Jak dotąd poświęcono mu jedynie kilka drobnych publikacji: Julian BARTOSZEWICZ, „Franciszek Bieliński”, Tygodnik Ilustrowany, 1863, nr 183, s. 117-118, 134, 145-147); Ignacy BARANOWSKI, Marszałek Franciszek Bielinski, Warszawa 1919; Helena WANICZKÓWA, „Bieliński Franciszek h. Junosza”, [w:] PSB, t. I, s. 47-50, Warszawa-Kraków 1935; Stanisław ACHREMCZYK, „Bieliński Franciszek h. Junosza (ok. 1683-1766)", [w:] Stownik biograficzny Pomorza Nadwiślańskiego, red. Stanisław GIERSZEWSKI, t. I, Gdańsk 1992, s. 100-101.

${ }^{3}$ Zbigniew REWSKI, „Fontana Józef, (ok. 1670-ok. 1741)”, [w:] PSB, t. VII, Kraków 1948-1958, s. 56-57; BARTCZAKOWA, Jakub Fontana ..., s. 14, 17; Wojciech BOBERSKI, „Fontana (Fontanna, Fontani) Giuseppe Giacomo (Józef, Joseph)", [w:] Allgemeines Künstlerlexicon. Die Bildenden Künstler aller Zeiten und Völker, t. 27, München-Leipzig 2004,
} 
Przypuszczalnie odpowiadał za wzniesienie pałacu Franciszka Bielińskiego przy ulicy Królewskiej, być może zaangażowany był również w przebudowę pałacu Bielińskich w Otwocku ${ }^{4}$. W skapych archiwaliach nie ma, niestety, żadnych dokładnych dat prowadzenia owych budów, których związek z Giuseppe Fontaną sugeruje głównie treść jego testamentu z $1739 \mathrm{r}^{5}$

Udokumentowane związki Franciszka Bielińskiego z warszawskim budowniczym sięgają co najmniej 1721 r. Wówczas to cześnik koronny na zlecenie Elżbiety Sieniawskiej doglądał „fabryki” pałacu w Wilanowie, przy której pracował m.in. właśnie Giuseppe Fontana ${ }^{6}$. Z kolei w 1725 r. na prośbę tegoż Fontany pośredniczył w uzyskaniu zgody hetmanowej na urządzenie przezeń cegielni w Kabatach ${ }^{7}$. Kontakty z budowniczym utrzymywał nowo mianowany marszałek nadworny również w 1732 r., a to w związku z odpowiedzialnością za realizację planów uporządkowania sieci ulicznej Warszawy. To właśnie Giuseppe Fontana miał pomagać architektowi włoskiemu Gaetanowi Chiaveriemu, przyjętemu do służby Augusta II wiosną tegoż roku, w pracach nad pomiarami stołecznych ulic, oszacowaniem wartości stojących przy nich budynków oraz wytyczeniem kanałów ${ }^{8}$. Musiał zapewne cieszyć się sławą dobrego fachowca oraz doradcy w sprawach budownictwa ${ }^{9}$. Trzy lata później burgrabia warszawskiego pałacu Radziwiłłów, Krzysztof Mioduszewski, skarżył się jednak marszałkowi Bielińskiemu na jego architekta „Fontaniego”, który wcześniej (zapewne w 1732 r.) zaprojektował kanał między pałacem radziwiłłowskim, a klasztorem wizytek, na złe wykonanie tejże inwestycji, skutkujące podmywaniem murów tak pałacu, jak i klasztoru. W odpowiedzi miał usłyszeć od marszałka, że ,,architekt to czynił, com ja rozkazał, jak wiele pieniędzy wystarczyło, to za to tak wiele robił"10.

Urodzony w Szczuczynie Jakub Fontana, zgodnie z wzmiankowanym wyżej testamentem ojca miał udać się za rodzicielskie pieniądze na dość kosztowne studia do Włoch i Paryża ${ }^{11}$. Pobyt syna za granicą przypadł zapewne na lata ok. 1731-1732 (1733?) i był krótszy niż wcześniej sądzono ${ }^{12}$. Wiemy, że na pewno już w styczniu 1732 r. Jakub przebywał w Paryżu, o czym informował wojewodę ruskiego Augusta Czartoryskiego jego

s. 123-124; Monika WYSZOMIRSKA, „Fontana (Fontanna, Fontani) Giuseppe Giacomo (Józef) (1676-ok. 1739/ 1741)”, [w:] Słownik architektów i budowniczych środowiska warszawskiego..., s. 131-137.

${ }^{4}$ BARTCZAKOWA, Jakub Fontana..., s. 17; Jakub SITO, Wielkie warsztaty rzeźbiarskie Warszawy doby saskiej. Modele kariery - formacja artystyczna - organizacja produkcji, Warszawa 2013, s. 277-278.

${ }^{5}$ Zbigniew REWSKI, „Działalność architektoniczna warszawskich Fontanów”, Biuletyn Historii Sztuki i Kultury, R. II: 1933/1934, nr 4, s. 267-268. Oryginał testamentu spłonął w 1944 r.

${ }^{6}$ F. Bieliński do E. Sieniawskiej z Warszawy, 16 I 1721, Biblioteka Czartoryskich (dalej: BCzart), sygn. 2711 III, s. 488.

${ }^{7}$ F. Bieliński do E. Sieniawskiej z Warszawy, 18 I 1725, BCzart., sygn. 2711 III, s. 769-770.

${ }^{8}$ Jerzy DYGDAŁA, „Wcześniej niż Komisja Brukowa? Próby uporządkowania Warszawy w latach trzydziestych XVIII wieku", Almanach Warszawy, 2015, t. 9, s. 129-149.

${ }^{9}$ BOBERSKI, Fontana (Fontanna, Fontani) Giuseppe Giacomo (Józef, Joseph II), s. 123.

${ }^{10}$ K. Mioduszewski do A. Radziwiłłowej z Warszawy, 6 VII 1735, Archiwum Główne Akt Dawnych (dalej: AGAD), Archiwum Radziwiłłów (dalej: AR), dz. V, nr 9733 II, s. 51-52; cyt. za: DYGDAŁA, „Wcześniej niż Komisja Brukowa...", s. 146.

${ }^{11}$ REWSKI, „Działalność architektoniczna...”, s. 270; BARTCZAKOWA, Jakub Fontana ..., s. 19.

12 Bartczakowa (Jakub Fontana ..., s. 19) przesuwała go na lata 1731 - do ok. 1736-1737. Na lata 1731-1733 wskazał Sito (Wielkie warsztaty..., s. 266). Już w 1734 r. Jakub Fontana zdążył rozpoczać budowę kościoła i klasztoru Benedyktynek w Drohiczynie fundacji Wiktoryna Kuczyńskiego, kasztelana podlaskiego; zob. Bartłomiej KACZOROWSKI, „Fundacje i sprawy artystyczne w «Państwie Boćkowskim» Józefa Franciszka Sapiehy”, Biuletyn Historii Sztuki, R. L: 1988, nr 1-2, s. 68; Jerzy KOWALCZYK, „Rola Rzymu w późnobarokowej architekturze polskiej”, Rocznik Historii Sztuki, R. XX: 1994, s. 275; Wiktoryn KUCZYŃSKI, Pamiętnik 1668-1737, Białystok 1999, s. 7, 60, 111-112. 


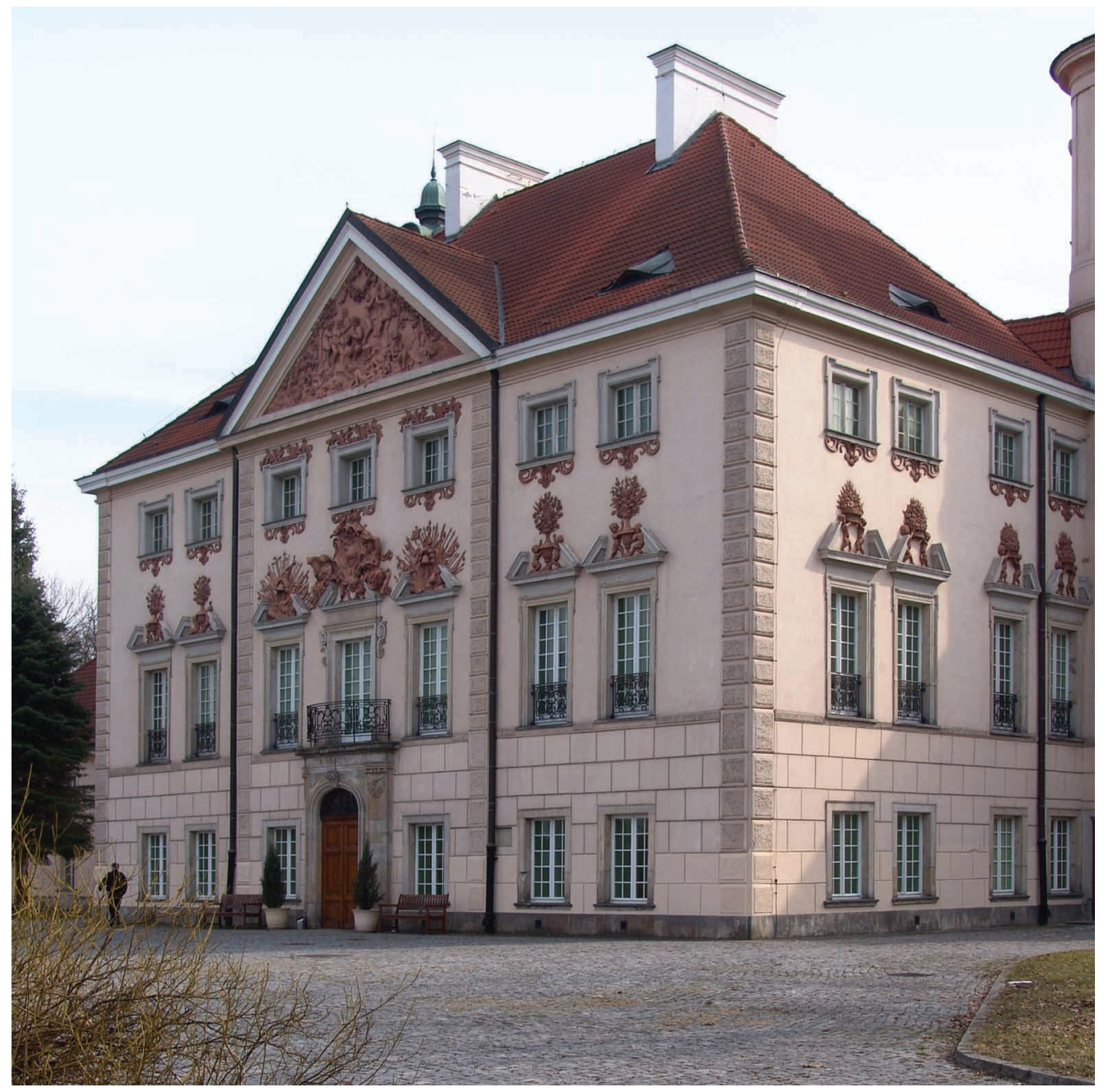

1. Pałac Franciszka Bielińskiego w Otwocku Wielkim, wzniesiony po 1668, 1682 do ok. 1690, ok. 1725, przeksztatcony 1741 do ok. 1760

wedtug projektu Jakuba Fontany, widok od frontu. Fot. Monika Wyszomirska

pośrednik handlowy niejaki Devalcourt ${ }^{13}$. Jest bardzo prawdopodobne, że pobyt młodego Fontany w stolicy Francji poza pieniędzmi ojca mógł być przynajmniej częściowo sfinansowany przez Franciszka Bielińskiego, który z pewnością zadbał o stosowną rekomendację architekta u swojej siostry Katarzyny, żony byłego posła francuskiego w Rzeczypospolitej, Jeana Victora de Besenvala ${ }^{14}$. Bardzo prawdopodobne jest, iż Fontana zetknął się wówczas bezpośrednio z pracującym dla Besenvalów Juste-Aurelem Meissonierem, francuskim architektem i złotnikiem, u którego, jak wiadomo, Bieliński (zapewne za pośrednictwem siostry) zamówił ok. 1731-1732 r. słynny gabinet przeznaczony do jego warszawskiego pałacu ${ }^{15}$.

\footnotetext{
${ }^{13}$ BARTCZAKOWA, Jakub Fontana ..., s. 19, 21; Jacek GAJEWSKI, „Nagrobek Jana Tarly w Warszawie i zagadnienia jego rekonstrukcji (mała architektura w twórczości Jakuba Fontany; Plersch i warsztat)", Arteria. Rocznik Wydziatu Sztuki Politechniki Radomskiej, 2012, nr 10, s. 89-90.

${ }^{14}$ Możliwość taką rozważał Jakub Sito (Wielkie warsztaty..., s. 267).

${ }^{15}$ GAJEWSKI, „Nagrobek Jana Tarly...”, s. 89-91; SITO, Wielkie warsztaty..., s. 267-269. Na temat salonu zob. Samanta POPOW, „Meissonierowski salon Franciszka Bielińskiego - historia rokokowej dekoracji dworu magnackiego”, [w:] Dwory magnackie w XVIII wieku. Rola i znaczenie kulturowe, red. Teresa KOSTKIEWICZOWA, Agata ROĆKO, Warszawa 2005, s. 295-320. Gabinet prezentowany był publicznie w Paryżu w 1735 r.
} 


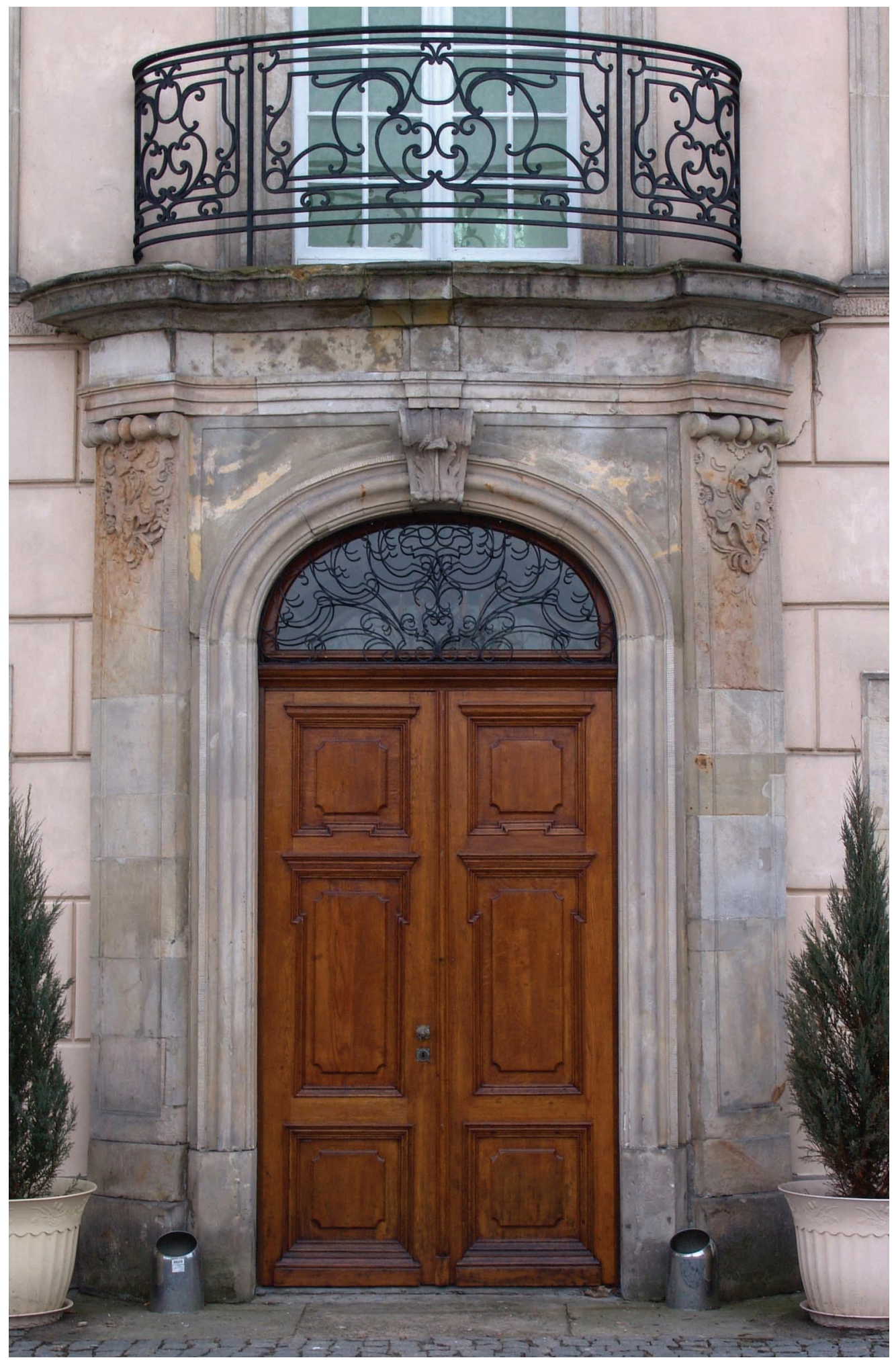

2. Jakub Fontana (projekt), portal główny pałacu Franciszka Bielińskiego w Otwocki Wielkim, 1757. Fot. Monika Wyszomirska 


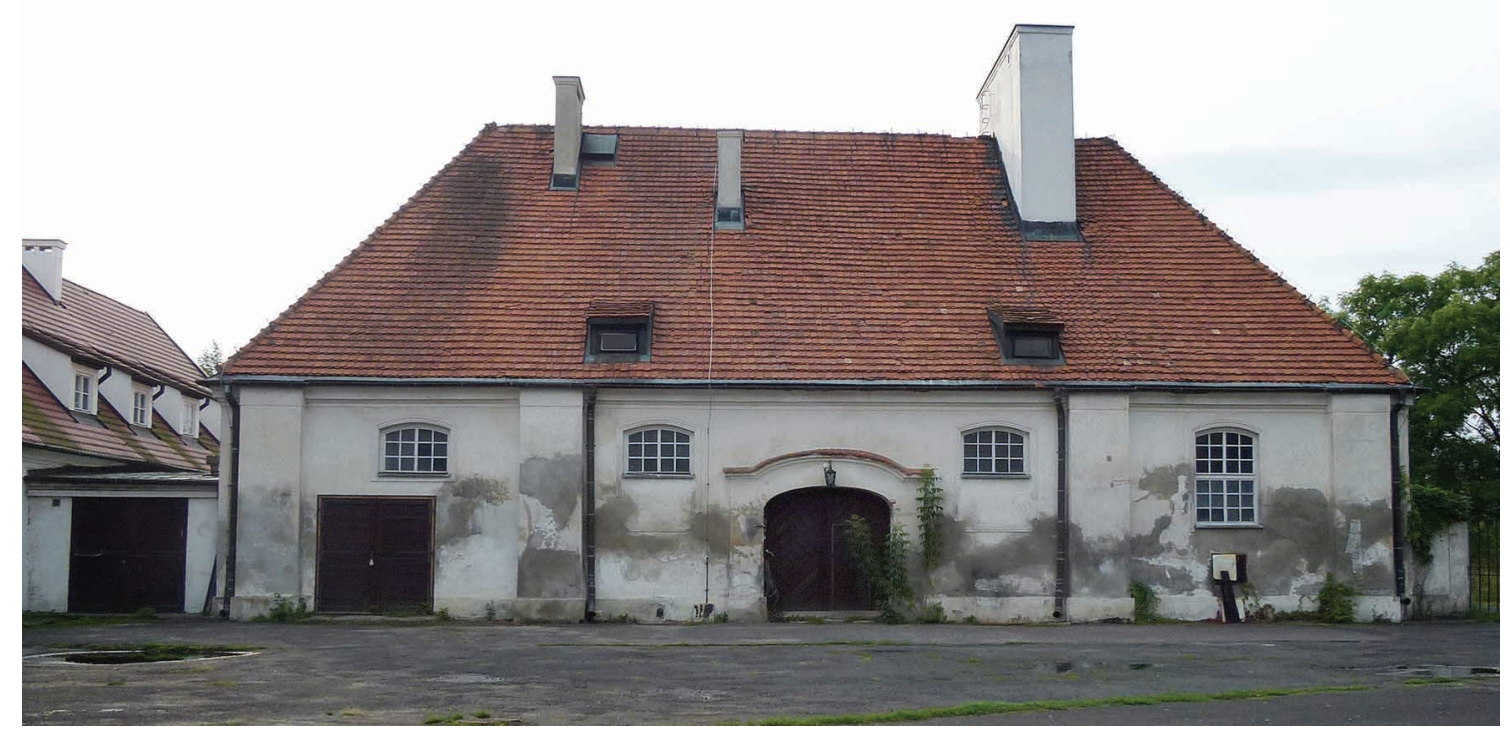

3. Jakub Fontana (projekt), spichrz przy rezydencji Franciszka Bielińskiego w Otwocku Wielkim, ok. 1760, widok od dziedzińca. Fot. Monika Wyszomirska

Aldona Bartczakowa z braku innych przekazów źródłowych stwierdziła, że mogła to być jedyna podróż zagraniczna Jakuba ${ }^{16}$, podczas której nie tylko poznał wspaniałe dzieła architektoniczne, lecz być może przywiózł także notatki rysunkowe i wzorniki graficzne, z których korzystał przez całe swoje twórcze życie. We Włoszech młody Fontana mógł przebywać w kilku ośrodkach, przede wszystkim w rodzinnej Valsoldzie i w Rzymie (na co wskazuje analiza jego twórczości, zwłaszcza wczesnej), ale to właśnie wzory francuskie zarówno klasyczne, jak i aktualne rokokowe wywarły na nim najsilniejsze wrażenie, zwłaszcza w przypadku architektury pałacowej ${ }^{17}$. Nie był to jednak, jak się okazuje, jedyny pobyt Fontany w Paryżu, do czego za chwilę przyjdzie powrócić.

Po śmierci Giuseppe Fontany (ok. 1739-1741) Jakub przejął wszystkie „fabryki” ojca, przy których z pewnością od dłuższego czasu pracował, najpierw w charakterze pomocnika, a później (zwłaszcza po powrocie z zagranicy) w charakterze projektującego architekta. Najwcześniejsze z zachowanych źródeł pozwalają udokumentować i datować początek współpracy Jakuba Fontany z Franciszkiem Bielińskim co najmniej na wczesne lata 40. XVIII w., kiedy to prowadzone były prace w rezydencjach w Otwocku i Warszawie, a także przy kościele parafialnym w Karczewie ${ }^{18}$. Ponadto w tym właśnie czasie Fontana stał się głównym architektem Komisji Brukowej (od 1742 do 1761), której przewodniczył marszałek Bieliński. Architekt wykonywał w jej ramach pomiary gruntów, prace przy brukowaniu ulic i wytyczaniu kanałów. Dokonywał też wizji Zamku Królewskiego, którego utrzymanie i zabezpieczenie jako budowli państwowej należało zarówno do obowiązków podskarbiego wielkiego, jak i właśnie marszałka koronnego. Z tego okresu pochodzi znany list Franciszka Bielińskiego do sędziego grodzkiego warszawskiego Teodora Szydłowskiego (napisany przypuszczalnie w 1745 r.), w którym marszałek wyraził opinię na temat Jakuba Fontany,

\footnotetext{
${ }^{16}$ BARTCZAKOWA, Jakub Fontana ..., s. 19.

${ }^{17}$ KOWALCZYK, „Rola Rzymu...”, s. 222.

${ }^{18}$ Karol GUTTMEJER, „Kościół w Karczewie pod Warszawą”, Kwartalnik Architektury i Urbanistyki, R. 37: 1992, z. 4, s. 319-322.
} 
będącą dewizą ich wzajemnego stosunku, wspomniał bowiem, że to „pryncypalny w kraju naszym architekt, a partykularny mój, człowiek zaś rzetelności swojej"19. Wydaje się, że cytat ten może upoważniać do traktowania Jakuba Fontany jako sui generis nadwornego architekta Bielińskiego.

Kolejne zlecenia, które Fontana realizował dla marszałka, to poza kontynuacja „fabryk" otwockiej i warszawskiej, trwających co najmniej do 1760-1761, także organizacja uroczystości pogrzebowych i projekt castrum doloris dla żony marszałka, Doroty Henrietty z Przebendowskich w stołecznym kościele Reformatów w 1755 r., zaprojektowanie w tym samym roku jej nagrobka tamże (w istocie przekształcenie starszego pomnika ojca zmarłej Jana Jerzego), zaprojektowanie i wzniesienie kościoła i klasztoru Bernardynów w Górze Kalwarii (1755-1760), w końcu niemal równolegle prace przy założeniu i zabudowie jurydyki Bielino (ok. 1757).

\section{Prace Jakuba Fontany w glównych rezydencjach Franciszka Bielińskiego: Otwock i Warszawa}

Trwające ponad czterdzieści lat „władanie” przez Franciszka Bielińskiego pałacem w Otwocku (il. 1), odziedziczonym po śmierci ojca Kazimierza Ludwika w 1713 r., powstałym w końcu XVII w. (po 1682), którego autorstwo często przypisywane jest Tylmanowi van Gameren ${ }^{20}$, wiązało się m.in. z prowadzoną w kilku etapach przebudową dawnej willi Bielińskich, z parą alkierzy od strony ogrodu (od południa) i ośmiobocznym salonem na osi. Poza tym prace dotyczyły oficyn, parku z jego urządzeniami i budynków gospodarczych.

Dokonana w połowie XVIII w. przez Jakuba Fontanę $e^{21}$ zasadnicza modernizacja korpusu pałacu w duchu francuskiego rokoka oznaczała przede wszystkim - zgodnie z doktryną XVIII-wieczną - „dowartościowanie” parteru poprzez przeniesieniem tam z piętra apartamentów mieszkalnych. W związku z tym architekt zniósł wachlarzowe schody zewnętrzne prowadzące pierwotnie na piętro i w miejsce dawnego pokoju w północno-zachodnim narożniku korpusu wbudował typową dla XVIII-wiecznej architektury francuskiej boczną klatkę schodową z kamiennymi (zapewne wykonanymi z białego marmuru) schodami powrotnymi o krętym biegu ${ }^{22}$. Fontana wystawił także wykonany w pia-

\footnotetext{
${ }^{19}$ F. Bieliński do T. Szydłowskiego z Otwocka, [b. d.] ,[1745], AGAD, Archiwum Komierowskich (dalej: Arch. Kom.), sygn. 9/9, s. 360; SITO, Wielkie warsztaty..., s. 265.

${ }^{20}$ Za autorstwem Tylmana opowiadają się: Adam MIŁOBĘDZKI, Architektura polska XVII wieku, t. 1, Warszawa 1980, s. 375; Zofia BARANOWSKA, „Pałac w Starym Otwocku (Z historii budowy w XVIII i przebudowy w XIX stuleciu)”, Rocznik Historii Sztuki, R. XVIII: 1988, s. 263; Anna FELIKS, „O ciekawym przedwojennym projekcie rewaloryzacji i powojennych adaptacjach wnętrz pałacu w Otwocku Wielkim”, [w:] Wartość funkcji w obiektach zabytkowych, red. Bogusław SZMYGIN, Warszawa 2014, s. 113; Jolanta Putkowska wyraziła opinię, że pałac w Otwocku był ,,projektowany być może przez Tylmana z Gameren"; zob. Jolanta PUTKOWSKA, Architektura Warszawy XVII wieku, Warszawa 1991, s. 164). Stanisław Mossakowski w najnowszej monografii Tylmana z Gameren napisał, że pałac w Otwocku powstał pod wpływem bezpośredniego oddziaływania sztuki architekta, nie wskazał jednak wprost na jego autorstwo, odżegnując się od niego, jak można się domyślać; zob. Stanisław MOSSAKOWSKI, Tylman z Gameren (1632-1706). Twórczość architektoniczna w Polsce, Warszawa 2012, s. 61.

${ }^{21}$ Jolanta PUTKOWSKA, Warszawskie rezydencje na przedmieściach i pod miastem $w$ XVI-XVIII wieku, Warszawa 2016, s. 141-143. Bartczakowa (Jakub Fontana ..., s. 135-137) z braku źródeł sceptycznie odnosiła się do możliwości ustalenia udziału Jakuba Fontany w przebudowie pałacu w Otwocku, za pewnik uważając jedynie jego prace przy budynkach gospodarczych.

22 Jan HINZ, „Dawny pałac w Otwocku”, [w:] Szkice architektoniczne krajowych dzieł sztuki, Warszawa 1889, t. 1, s. 19; Henryk SIUDER, Zespót pałacowy w Starym Otwocku. Badania architektoniczne, dokumentacja dla Oddziału
} 


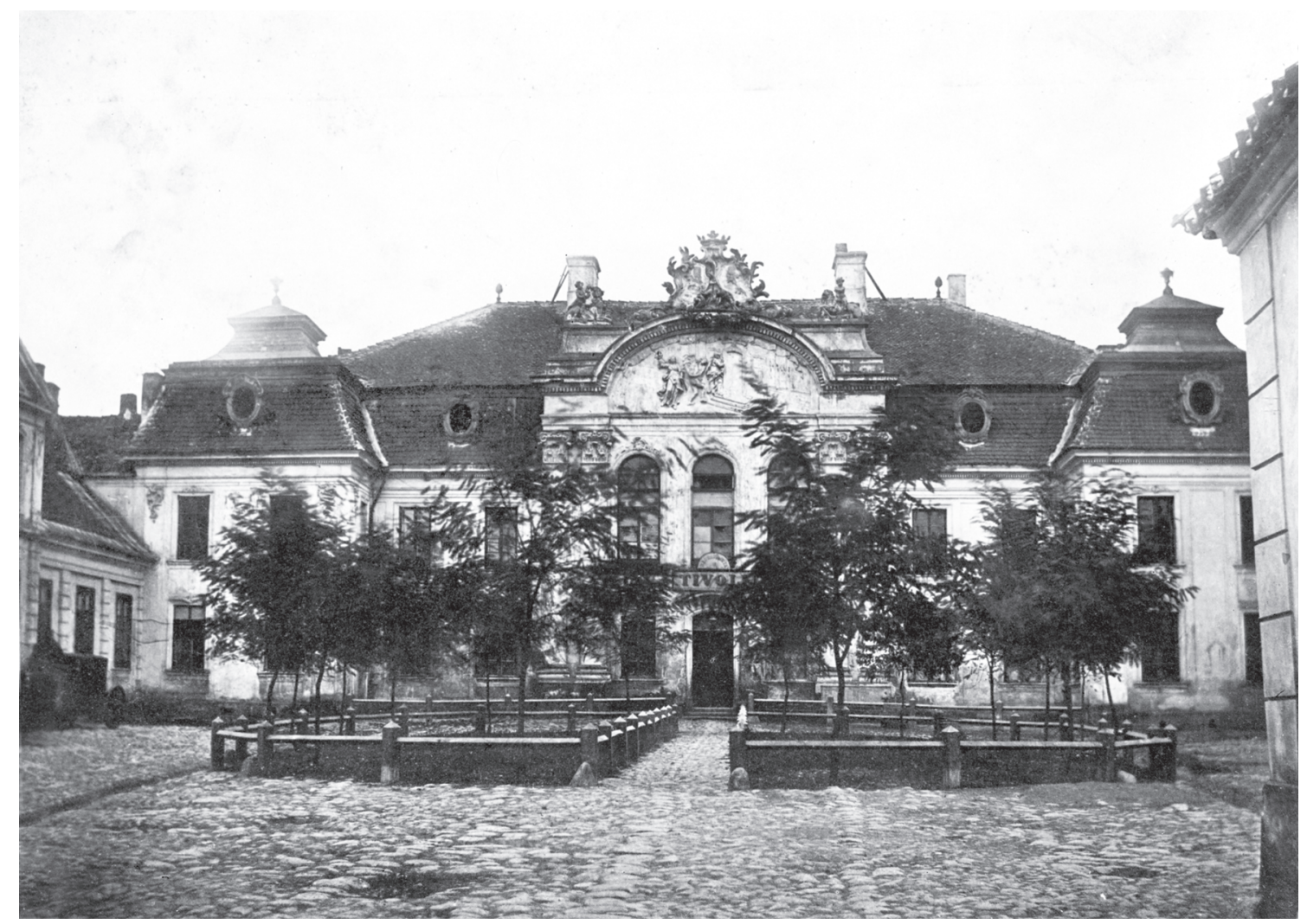

4. Pałac Franciszka Bielińskiego przy ul. Królewskiej w Warszawie, przed 1722, gruntownie przeksztatcony ok. 1744 do ok. 1752/1753 wedlug projektu Jakuba Fontany, zburzony 1895, elewacja frontowa. Fot. przed 1895, IS PAN

skowcu, zachowany do dziś, ondulowany portal główny, ozdobiony ornamentem rocaille (il. 2), niemal identyczny z Fontanowskimi portalami kościoła w Jedlińsku (1752) i w kamienicy Prażmowskich przy Krakowskim Przedmieściu w Warszawie (przed $1760)^{23}$. Po przebudowie korpusu wejście prowadziło do nowej sieni, za którą znajdowała się pierwotna ośmioboczna sala, teraz służąca przypuszczalnie jako jadalnia ${ }^{24}$.

Po bokach pałacu od strony ogrodu wzniesiono oficyny o prostej architekturze: wschodnią wolnostojącą i zachodnią połączoną galerią arkadową z korpusem. Budynki te mieściły stancje dla gości oraz oficjalistów dworskich, izby dla służby, kuchnię i inne pomieszczenia gospodarcze. W głębi rezydencji usytuowano spichlerz (il. 3), stajnię, browar i słodownię ${ }^{25}$. Przypuszczalnie autorstwa Fontany jest także rozplanowanie terenu na północ od pałacu ${ }^{26}$.

Zofia Baranowska, powołując się na Gerarda Ciołka, uznała, że otwocki park został założony wraz z budową pałacu w końcu XVII w. (rzekomo w konsultacji z Tylmanem), a geometrycznie rozplanowany ogród od strony południowej miał mieć w swej części

\footnotetext{
Warszawskiego PKZ, 1973, Narodowy Instytut Dziedzictwa w Warszawie (Oddział w Grodzisku Mazowieckim); BARANOWSKA, „Pałac w Starym Otwocku...”., s. 266-267.

${ }^{23}$ BARTCZAKOWA, Jakub Fontana ..., s. 136.

${ }^{24}$ Jolanta PUTKOWSKA, ,Warszawski zespół rezydencjonalny Franciszka Bielińskiego marszałka wielkiego koronnego", Kwartalnik Architektury i Urbanistyki, R. 41: 1996, nr 1, s. 33.

${ }^{25}$ BARTCZAKOWA, Jakub Fontana..., s. 136-140; BARANOWSKA, „Pałac w Starym Otwocku...”, s. 266.

${ }^{26}$ PUTKOWSKA, „Warszawski zespół rezydencjonalny...”, s. 36.
} 


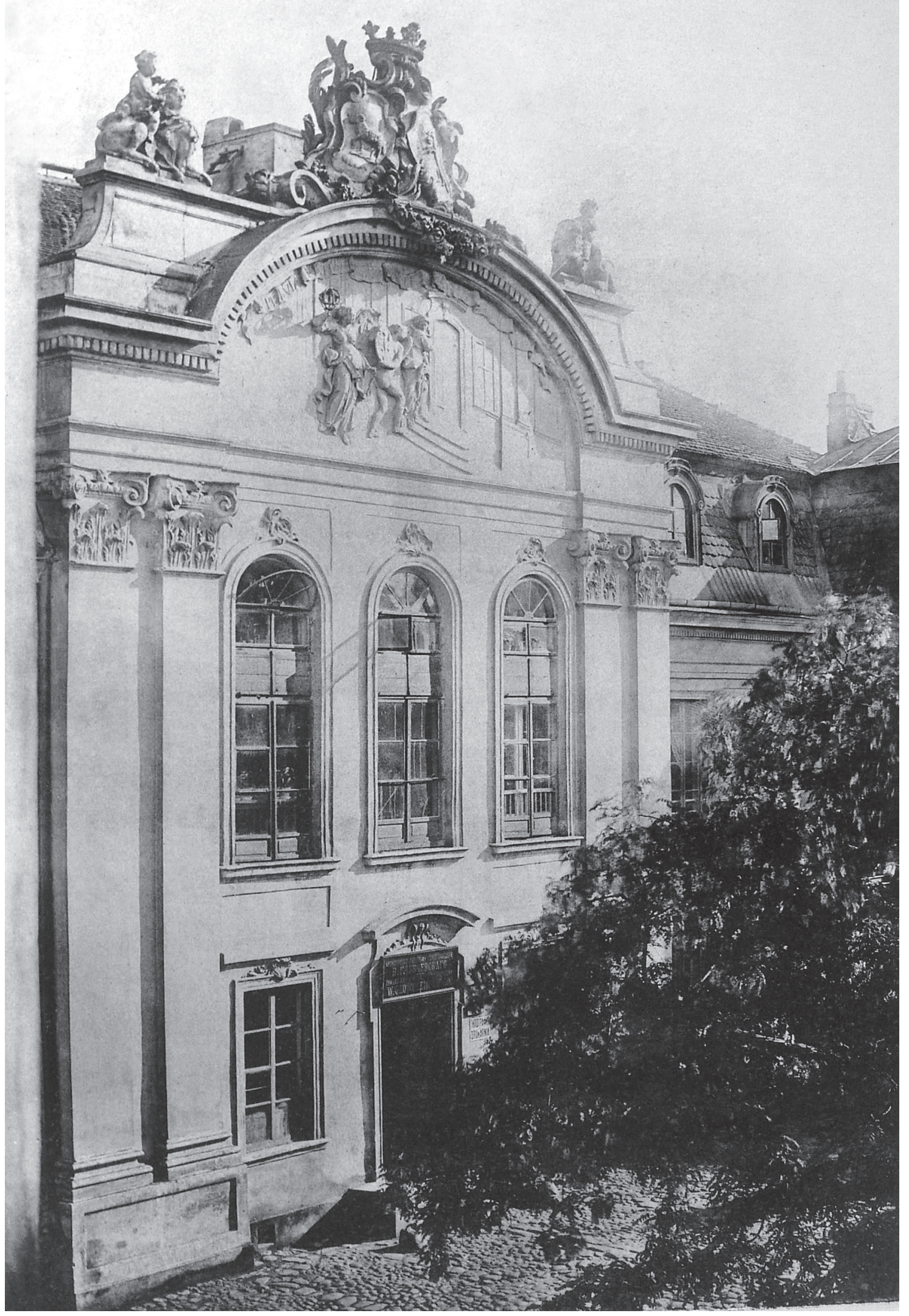

5. Pałac Franciszka Bielińnkiego przy ul. Królewskiej w Warszawie, przed 1722, gruntownie przeksztatcony ok. 1744 do ok. 1752/1753 wedlug projektu Jakuba Fontany, zburzony 1895, ryzalit główny. Fot. przed 1895, IS PAN 
środkowej wielki salon ${ }^{27}$. Według Jolanty Putkowskiej tenże salon miał ulec w latach 40. XVIII w. radykalnej przemianie ${ }^{28}$, a kolejne przekształcenia ogrodu zmierzały do powiększenia programu rekreacyjnego i gospodarczego rezydencji. Pomysłodawcą wszystkich tych przeobrażeń miał być rzecz jasna Jakub Fontana ${ }^{29}$.

Fontanowska modernizacja rezydencji otwockiej, być może dwu- lub więcej etapowa, rozpoczęła się w $1741 \mathrm{r}$. i w odniesieniu do corps-de-logis pałacu trwała co najmniej do 1757 r., na co wskazywałaby tablica na elewacji północnej informująca, iż Franciszek Bieliński ,aedificavit [pałac] 1757"30. Z zachowanych fragmentarycznie archiwaliów wiemy na pewno, że Jakub Fontana w 1743 r. wybudował pałacową kuchnię oraz browar ${ }^{31}$, a także, iż w 1746 r. marszałek oczekiwał na ładunek wapna przeznaczony dla trwających „od dwóch lat fabryk" pałacu warszawskiego oraz pałacu w dobrach otwockich. Paszport na wapno wystawiony przez Bielińskiego 15 marca $1746 \mathrm{r}$. nie informował o zakresie prowadzonych prac, nadmieniał jedynie, że przebiegały one równolegle w obu rezydencjach ${ }^{32}$.

Wraz ze wzrostem ministerialnej pozycji Bielińskiego, Jakub Fontana we współpracy z licznym gronem artystów i rzemieślników dokonał również przebudowy warszawskiego pałacu marszałka przy ulicy Królewskiej ${ }^{33}$ (il. 4). Wedle literatury przedmiotu prace trwające w ciągu lat 40. (do ok. 1750), objęły m.in. gruntowną przebudowę starszego korpusu, pochodzącego nie jak się powszechnie uważa z lat 30., ale z początku lat 20. XVIII w. ${ }^{34}$, wystawionego przez Giuseppe Fontanę. Jakub poszerzył gabaryt budowli, rozbudował apartamenty, założył nowy dekoracyjny dach, zaprojektował całkowicie nowa fasadę w duchu rokoka francuskiego i nowy wystrój wnętrz ${ }^{35}$. Autorem rzeźb na fasadzie był zapewne Johann Georg Plersch (il. 5), detal kamieniarski wykonał Michael Dollinger, wnętrza dekorował zespół pod kierunkiem Johanna Georga Plerscha (z udziałem m.in. Franza Antona Vogta) ${ }^{36}$. Można przypuszczać, że prace te, podobnie jak w Otwocku, odbywały się w co najmniej dwóch etapach. Jeden z nich rozpoczął się około 1744 r., o czym jednoznacznie informował wspomniany wyżej paszport na wapno z datą 15 marca 1746 r. ${ }^{37}$ Przypomnijmy, że Bieliński wspomniał w nim o „fabrykach” pałacu warszawskiego oraz pałacu w dobrach otwockich, ciągnących się „od dwóch lat”.

\footnotetext{
${ }^{27}$ BARANOWSKA, „Pałac w Starym Otwocku...”, s. 264.

${ }^{28}$ PUTKOWSKA, „Warszawski zespół rezydencjonalny...”, s. 37.

${ }^{29}$ PUTKOWSKA, Warszawskie rezydencje..., s. 145.

30 BARTCZAKOWA, Jakub Fontana..., s. 136; Mariusz KARPOWICZ, „«Sala Horacego» w Starym Otwocku. Z rozważań nad antykizacją treści”, [w:] Muzeum i twórca. Studia z historii sztuki i kultury ku czci Prof. dr Stanisława Lorentza, Warszawa 1969, s. 327; id., „Horacy, czyli o pałacu w Otwocku Wielkim”, [w:] id., Sztuka oświeconego sarmatyzmu. Antykizacja i klasycyzacja w środowisku warszawskim czasów Jana III, Warszawa 1984, s. 120.

${ }^{31}$ Rachunek ad ultimam Junij 1743, AGAD, Archiwum Gospodarcze Wilanowskie, Anteriora, 297a, s. 289, zob. GUTTMEJER, „Kościół w Karczewie...”, s. 316, 326.

${ }^{32}$ Paszport, Otwock, 15 III 1746, AGAD, Arch. Kom., sygn. 9/9, s. 531.

33 PUTKOWSKA, „Warszawski zespół rezydencjonalny...”, s. 17-46; POPOW, „Meissonierowski salon...”, s. 295307; SITO, Wielkie warsztaty..., s. 277-278.

${ }^{34}$ Sprawę szczegółowego datowania pałacu omawiam szerzej w przygotowywanej monografii Franciszka Bielińskiego. W tym miejscu warto jedynie wspomnieć, że zachował się jego list do podskarbiego Jana Jerzego Przebendowskiego z 1722 r., w którym ówczesny cześnik koronny prosił wpływowego ministra o interwencję w sprawie statku niesłusznie zarekwirowanego na komorze celnej w Fordonie koło Bydgoszczy, zawierającego cenny ładunek dwóch zwierciadeł, „które sobie umyślnie w Berlinie do pałacu mego warszawskiego, według pewnej miary zapisać i zrobić kazałem i do Gdańska stamtąd nie bez kosztu odesłane teraz na tymże statku sprowadzone"; zob. F. Bieliński do J.J. Przebendowskiego z Miętnego, 12 V 1722, AGAD, Archiwum Radziwiłłów, V-773, s. 15.

${ }^{35}$ SITO, Wielkie warsztaty..., s. 278.

${ }^{36}$ Ibid. s. 278.

${ }^{37}$ Paszport, 15 III 1746, AGAD, Arch. Kom., sygn. 9/9, s. 531.
} 
W świetle kolejnych źródeł czas trwania rozbudowy obu rezydencji, otwockiej i warszawskiej, można przesunąc dalej, do początków lat 50. XVIII w. Dysponujemy m.in. jeszcze jednym paszportem na wapno, wystawionym przez Bielińskiego w październiku 1750 r., który potwierdzał, iż marszałek oczekiwał spławu materiału budowlanego jesienią tegoż roku i wiosny roku następnego ,na pilną potrzebę fabryk moich tak w Warszawie, jako Dobrach Otwockich powyżej Warszawy leżących"38. Ładunek aż 70 łasztów wapna, pochodzący z Krakowa, został opłacony przez oficjalistę marszałka Michała Sokołowskiego oraz dostawcę Józefa Bylicę ${ }^{39}$. Wiosną 1751 r. okazało się, że brakuje wapna, toteż - zgodnie z listem sekretarza Bielińskiego, Adama Kępskiego - marszałek „pomiarkowawszy się z fabrykami, które tak w Warszawie, jako i w Otwocku są w oczach wszystkich ludzi, zamówił u JMC P. Bylicy wszystko wapno, co być spuszczone może"40.

Kto wie, czy np. pospieszny wyjazd Jakuba Fontany w sierpniu 1754 r. z placu budowy rezydencji cześnika koronnego Eustachego Potockiego w Radzyniu Podlaskim „dla różnych w Warszawie fabryk" ${ }^{\prime}$, nie był także związany z kontynuacją prac dla marszałka być może w Otwocku lub w Warszawie? W tym ostatnim przypadku chodzić musiało raczej o pomieszczenia gospodarcze, nie zaś o mieszkalne, skoro już w $1751 \mathrm{r}$. oczekiwano na transport czterech pak oraz skrzyni, ,zawierających 6 wielkich zwierciadeł do pałacu warszawskiego, [...] 6 krzeseł z drzewa orzechowego snycerską robotą wyrabianych, [...] 14 stołków takich że jak krzesła"42

Kolejne wzmianki źródłowe dotyczące pałaców warszawskiego i otwockiego pochodzą z lat 1759-1760. Na podstawie Księgi Ekspensy Franciszka Bielińskiego z 1760 r., odnalezionej przeze mnie niedawno w Archiwum Państwowym w Kielcach, wiadomo, że pewne przedsięwzięcia budowlane i dekoracyjne były w tym czasie (ponownie ?) prowadzone równolegle w obu pałacach ${ }^{43}$.

Jeśli chodzi o Otwock, obejmowały one obie oficyny pałacu, a także „szkołę końską”, czyli ujeżdżalnię (maneż), browar i słodownię oraz ogród, a nad całością prac czuwał w dalszym ciagu Jakub Fontana. W lutym 1760 r. czeladnik szklarza warszawskiego Jakuba Noskiego przez pięć tygodni instalował okna do nowych oficyn, w których miały znaleźć się 732 szyby $^{44}$. Z architektem Fontaną współpracował wspominany już kamieniarz Michael Dollinger, który w maju 1760 r. otrzymał od podskarbiego Rajmunda Magiera według kontraktu zawartego z Fontaną niewygórowaną kwotę 223 tynfów tytułem połowy zadatku na „robotę kamieniarską do ogrodu otwockiego"45. Być może chodziło o postumenty pod rzeźby, a może o fontannę, altanę bądź trejaż. Natomiast nieokreślonej budowli (ogrodowej?) w Otwocku dotyczyła zwózka kamienia polnego przez chłopów z różnych wsi należących do Bielińskiego w maju tegoż roku: dostarczyli oni „,6276 cetnarów i pół kamieni na fundamenta do fabryki otwockiej"46. Nie znając szczegółów wspomnianego kontraktu z Dollingerem, możemy jedynie przypuszczać, że autorem projektu wystroju ogrodu był znowu Jakub Fontana, znany skądinąd ze swojej niechęci do „stolar-

\footnotetext{
${ }^{38}$ Paszport na wapno, 16 X 1750, AGAD, Arch. Kom., sygn. 9/9, s. 766.

${ }^{39}$ Ibid.

${ }^{40}$ A. Kępski do Podgórskiego, pisarza komory czerskiej, 8 VI 1751, AGAD, Arch. Kom., sygn. 9/9, s. 764.

${ }^{41}$ E. Potocki do J.K. Branickiego z Radzynia 25 VIII 1754, AGAD, Archiwum Roskie - Korespondencja, (dalej: ARK), sygn. XVI/21; por. BARTCZAKOWA, Jakub Fontana ..., s. 78, 80.

42 Rzeczy, które idq z Paryża, AGAD, Arch. Kom., rkps 9/9, s. 766.

${ }^{43}$ Archiwum Państwowe w Kielcach (dalej: APK), Archiwum Ordynacji Myszkowskiej (dalej: AOM), sygn. 1207.

${ }^{44}$ APK, AOM, sygn. 1207, s. 29.

45 APK, AOM, sygn. 1207, s. 83.

${ }^{46}$ Ibid., s. 78.
} 
skiej roboty" w ogrodzie według ,gustu saskiego" "47. W tym samym miesiącu zapłacono murarzom i ich pomocnikom 868,28 florenów za dziewięciotygodniową pracę murarską obejmująca „,szkołę końską”, browar oraz dokończenie „różnej roboty w nowych oficynach" 48 .

Oprócz prac przy aranżacji ogrodu kontynuowano wykańczanie wnętrz oficyn pałacowych. Stolarz Antoni, rzemieślnik otwocki, układał podłogi na górze w ,nowych oficynach to jest szafarskiej stancyi i nad stancjami kuchmistrzowskiemi według ugody przez JMC Pana Fontanę uczynionej"49. Jego prace zostały wycenione na 126 florenów. W październiku kamieniarz Dollinger otrzymał zapłate 108 zł ,za kominek kamienny stargowany przez JmC Pana Fontanę, architekta, do Biblioteki w nowych oficynach kuchennych otwockich" ${ }^{50}$. Gdyby potraktować to stwierdzenie dosłownie, oznaczałoby to, że marszałek zaplanował wówczas przeniesienie biblioteki umiejscowionej pierwotnie w najwyższej kondygnacji pałacu do pomieszczenia w nowo wybudowanych oficynach. Tak chyba rzeczywiście było, ponieważ podobna informacja pojawiła się wcześniej przy okazji rachunku dla stolarza w sprawie wykonania posadzki „w Bibliotece w nowych oficynach" 51 . Z cytowanego źródła wynika, że Fontana negocjował cenę z Dollingerem i że udało mu się ostatecznie zmniejszyć koszty wykonania.

Na podstawie tej samej Księgi Ekspensy z 1760 r., dokładnie rejestrującej wydatki dworu Bielińskiego, wiadomo, że prace wykończeniowe w obrębie posesji pałacu marszałka w Warszawie, jak również we wnętrzach tegoż pałacu, trwały przez cały ten rok, a planowano też kolejne inwestycje obejmujące oficyny i inne pomieszczenia gospodarcze, o czym niżej. Można przypuszczać, iż to rozrastający się dwór Bielińskiego, pełen stałych rezydentów i gości, a także częste pobyty w nim bratanków marszałka, wymusiły podjęcie decyzji o rozbudowie.

Pracami budowlanymi w warszawskim pałacu kierował oczywiście Jakub Fontana ${ }^{52}$. W lutym 1760 r. warszawski ,stolarz regestrowy” Lehman otrzymał zapłatę 433 i 1 1/2 tynfa „za różną robotę podług podanego i moderowanego regestru to jest za odrzwi i fasonowane drzwi do stancji tych, gdzie mają stać IchMc Panowie starostowie [Franciszek i Stanisław Bielińscy, bratankowie marszałka - MW] nad wozowniami item za drzwi do stancji nowych kuchmistrzowskiej, u cukierniczki, do kurników nowo wymurowanych, za wrota do bramy idącej do drwalni i za stoły kuchenne"53. W tym czasie marszałek opłacił „Panu Reymanowi komisarzowi” kwotę 1930 zł i 18 gr ,za wybrane szkła różne z huty osieckiej i z magazynu warszawskiego od Pana Leopolda [Hoenischa - MW] na potrzebę Pańską"54. W tym samym miesiącu lutym wspominany Jakub Noski, szklarz warszawski,

\footnotetext{
${ }^{47}$ J. Fontana do E. Potockiego, 4 IV 1755, AGAD, APP, sygn. 170 T. II, s. 307; Wojciech BOBERSKI, „Splendor architekta. O «mediach sławy» w czasach nowożytnych”, [w:] Architekt - Budowniczy - Mistrz Murarski. Materiały z sesji naukowej Instytutu Sztuki PAN Warszawa, 24-25 listopada 2004 roku, red. Hanna FARYNA-PASZKIEWICZ, Małgorzata OMILANOWSKA, Jakub SITO, Warszawa 2007, s. 34 (tu błędnie podana nazwa zespołu i sygnatura).

48 Ibid., s. 93 (junius).

49 Ibid., s. 91.

${ }^{50}$ Ibid., s. 161. Wiemy, że mury starej kuchni zostały rozebrane w $1760 \mathrm{r}$.

${ }^{51}$ Ibid., s. 9.

52 BARTCZAKOWA, Jakub Fontana..., s. 134; SITO, Wielkie warsztaty..., s. 278, PUTKOWSKA, „Warszawski zespół rezydencjonalny...”, s. 17-46. Dodajmy, że w tym samym 1760 r. Fontana pracował m.in. nad przebudową pałacu Antoniego Lubomirskiego „Za Żelazną Bramą”, trzykrotnie otrzymując wynagrodzenie według zawartego wówczas kontraktu; zob. Tadeusz S. JAROSZEWSKI, Pałac Lubomirskich, Warszawa 1971, s. 18-19.

${ }^{53}$ APK, AOM, sygn. 1207, s. 23.

54 Ibid., s. 25.
} 
otrzymał zapłatę 160 tynfów „od roboty okien nowych do stancji nowo poczynionych w pałacu Pańskim warszawskim i od reparacji okien w tymże pałacu przez cały rok" 55 . W marcu 1760 r. na potrzeby pałacu warszawskiego zapłacono 600 złp. „Pani Słomińskiej", metrykantowej koronnej kancelarii mniejszej, za 20000 sztuk cegiet ${ }^{56}$. Dwa miesiące później podskarbi Rajmund Magier przekazał „Panu Dietrichowi”, gospodarzowi pałacu warszawskiego, najpierw kwotę 500 tynfów ,na fabrykę w tym pałacu teraz poczętą" ${ }^{\prime 57}$, do której wkrótce dodał kolejne 1000 tynfów „na ekspensę fabryczną"58. Potem nastapiły dalsze wypłaty na ten cel. W lipcu 1760 r. Magier zanotował w księdze wydatków, że od wyjazdu Bielińskiego do Otwocka 3 czerwca do chwili obecnej „na ekspensę fabryczną w pałacu Pańskim warszawskim” pobrał 4100 tynfów ${ }^{59}$. Informacja o „fabryce warszawskiej" powtórzyła się także w odniesieniu do rachunku dla kowala warszawickiego [z Warszawic na Mazowszu - MW], który uczestniczył w akcji ,wywożenia drzewa do Lądu Radwankowskiego [Kępa Radwankowska na warszawskiej Pradze - MW] nad Wisłę" ${ }^{\circ 0}$, a także w rachunku dla „Pana [Józefa] Bylicy”, obywatela krakowskiego, który „spławił wapna na fabrykę Pańską do Warszawy łasztów 8"61. Na początku października podskarbi marszałka Rajmund Magier zapłacił Fontanie 311 zł 18 gr za 8200 sztuk cegły „na fabrykę do Pałacu Pańskiego warszawskiego na przymurowanie stancji w tyle drwalni przy cukierni[czce]"62. Ponadto uregulował kwotę 240 zł za 3000 sztuk dachówki na pokrycie tych stancji. W tym samym miesiącu stale współpracujący z Fontaną wspominany kamieniarz Michael Dollinger otrzymał drugą część pieniędzy (282 zł i 14 gr) „od roboty kamieniarskiej do kraty w ogrodzie, alias prospektu na przeciwko Pałacu Pańskiego na miasteczko Bielin jurysdykcji Pańskiej"63. Zapewne chodziło o trejaż ogrodowy, być może w postaci kraty umocowanej w kamiennej konstrukcji, pełniącej rolę punktu (tarasu?) widokowego.

W listopadzie 1760 r. marszałek zapłacił Fontanie 320 zł za 8000 sztuk cegły, ,,wziętej na fabrykę Pańską w pałacu warszawskim a mianowicie na wymurowanie stajenki nowej dla Pana Latomusa w ulicy idącej od miasta Bielina i na wymurowanie dołu na kształt fosy pod perspektywą, która jest w ogrodzie Pańskim" ${ }^{64}$. W tym samym miesiącu sprowadzono z huty kanclerza Jana Małachowskiego w Końskich ,żelazną kratę do perspektywy w ogrodzie warszawskim od pałacu Pańskiego na miasteczko Bielin idącej" ${ }^{2}$. Wypłacono także należność różnym rzemieślnikom, między innymi stolarzowi Lehmanowi „,za różną robotę do Pałacu Pańskiego Warszawskiego i do oranżeryi Pańskiej według specyfikacji podanego i moderowanego regestru tynfów 792"66.

17 stycznia $1760 \mathrm{r}$. w warszawskim pałacu marszałka odbyła się uroczysta iluminacja z okazji rocznicy koronacji Augusta III na polskiego króla. Przygotowanie uroczystości pochłonęło wydatki na płótno śląskie niezbędne „,na obrazy i inskrypcye” (odpowiednio

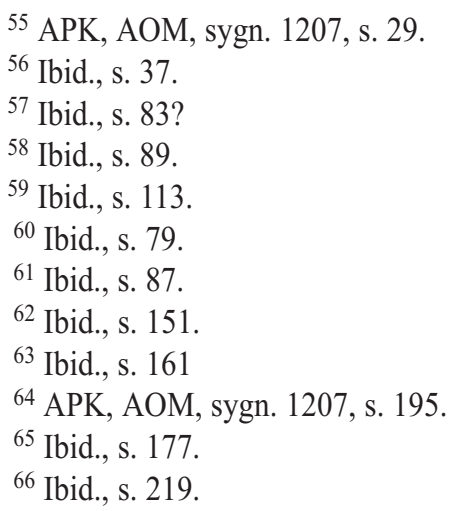




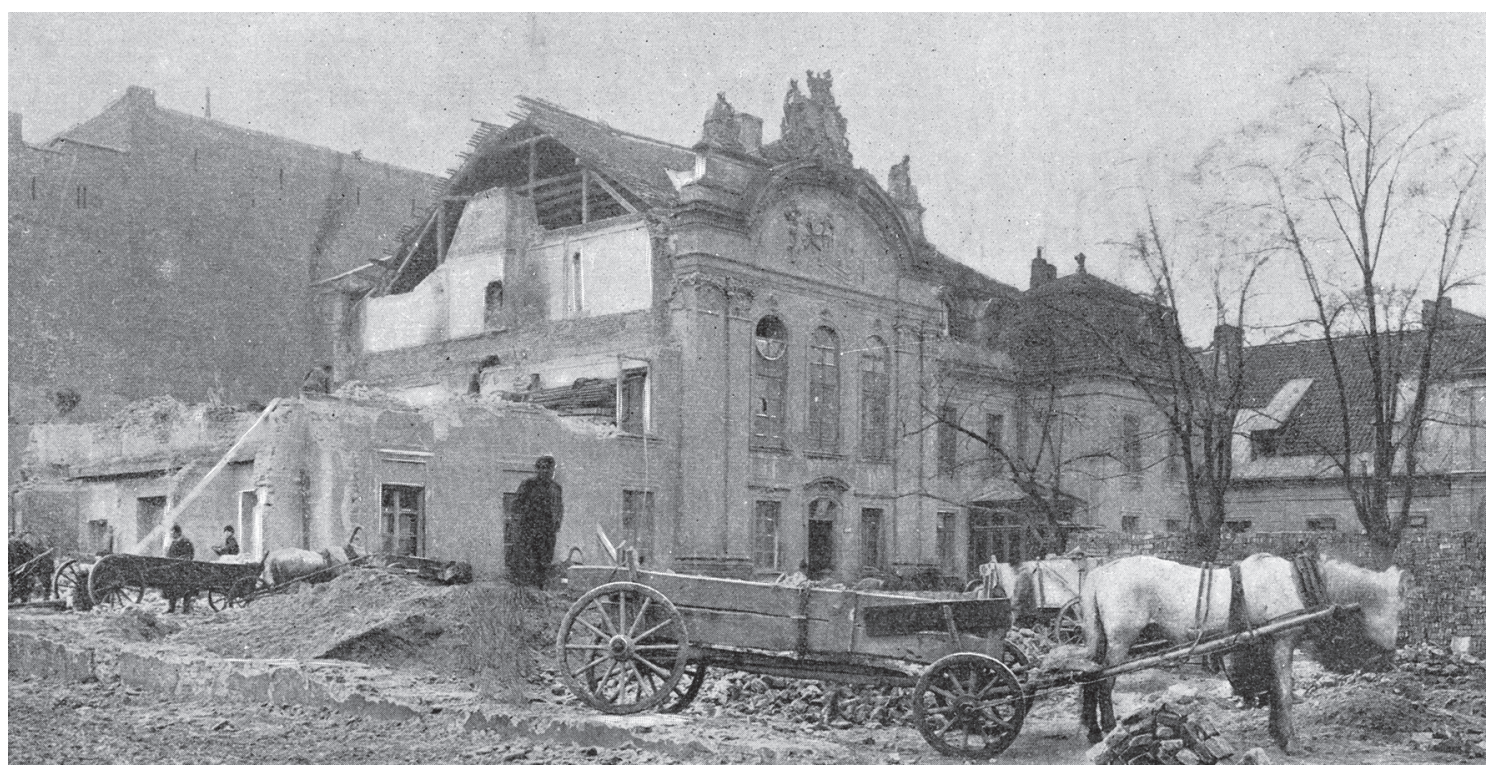

6. Pałac Franciszka Bielińskiego przy ul. Królewskiej w Warszawie, widok w trakcie burzenia, 1895

67 i 10 florenów), ponadto zapłatę 500 tynfów „Panu Plerschowi snycerzowi za oramenta wykliane z papieru i pozłacane, według ugody przez Jmc Pana Fontanę uczynionej"67. Wynagrodzenie w kwocie 356 tynfów otrzymał również niejaki „Pan Asmus”, malarz, za wymalowanie ,insygniów i inskrypcji według abrysu od Jmci Pana Fontany danego" 68. Widać z powyższego, że autorem projektu iluminacji pałacu i nadzorca jej wykonania był Jakub Fontana. Zakupiono także 146 funtów świec woskowych białych i 120 funtów świec żółtych. Wydatki na iluminację łącznie z transportem zamknęły się kwotą 2004 zł i 13 gr. Za tydzień dopisano jeszcze 567 zł i 14 gr wypłaconych Lehmanowi stolarzowi „za robotę stolarską na illuminację"69. Stolarza pozyskał Jakub Fontana i rzemieślnik ów pracował zapewne pod jego kierunkiem.

Nawet tak szczupłe przekazy źródłowe (a także nieliczne przekazy ikonograficzne) ukazują obraz okazałej, bogatej i zdobnej rezydencji, jaką był pałac Bielińskich przy ulicy Królewskiej. Sam fakt wieloetapowości i długotrwałości procesu budowy oraz zatrudnienia tak licznych artystów i rzemieślników wskazuje na jedną z największych warszawskich „fabryk” pałacowych XVIII w. Niestety, warszawski pałac marszałka od chwili śmierci pierwszego właściciela (1766) przez cały wiek XIX przekazywany z rąk do rąk został rozebrany w 1895 r. (il. 6).

Z powodu zniszczenia w 1944 r. ksiąg miejskich Warszawy nie można wprawdzie potwierdzić źródłowo udziału Jakuba Fontany przy zakładaniu w 1757 r. jurydyki Bielino ${ }^{70}$, aczkolwiek należy przypuszczać, że to właśnie on pracował przy projekcie układu urbanistycznego założenia powstającego z fundacji marszałka ${ }^{71}$. Jurydyka ta, nawiązująca być może do XVII-wiecznych inicjatyw urbanistycznych autorstwa Tylmana van Gameren, miała służyć rozwojowi Warszawy i wprowadzać ład w jej chaotyczniej zabudowie ${ }^{72}$.

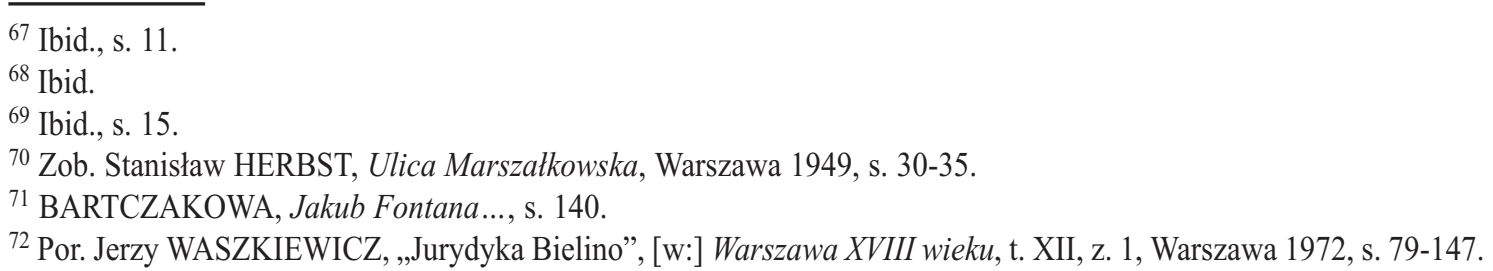




\section{Fundacje sakralne oraz, „castrum doloris”}

Wspomniana wyżej fundacja kościoła św. Wita w Karczewie koło Otwocka (il. 7) rysuje się w dość niejasny sposób. Piotr Bohdziewicz, który jako pierwszy zajął się budowlą, za czas jej powstania przyjął lata 1732-1737 i próbował powiązać ją z Jakubem Fontaną ${ }^{73}$. Atrybucję Bohdziewicza odrzuciła Aldona Bartczakowa ze względu na zbyt młody wiek architekta oraz jego pobyt za granica, który według niej miał trwać aż do ok. $1737 \mathrm{r}^{74}$ Jacek Gajewski przypisał autorstwo kościoła Carlowi Antoniowi Bayowi ${ }^{75}$. Z kolei Karol Guttmejer, przesuwając datę powstania świątyni na lata 1728-1732, początkowo utrzymał atrybucję Gajewskiego ${ }^{76}$, później zaś wysunął hipotezę, iż autorem projektu kościoła mógł być Giovanni Spazzio, domniemany autor pałacu Przebendowskich w Warszawie ${ }^{77}$. Ten ostatni zmarł jednak w 1726 r., nie mógł więc zrealizować tego projektu. Można przypuszczać, że jego autorem był jednak Carlo Antonio Bay (zmarły ok. 1740 r.), jak pierwotnie uważał Guttmejer, zaś Jakub Fontana, oddany przez ojca na naukę do Baya ${ }^{78}$, już wówczas mógł pracować przy budowie kościoła karczewskiego. Na pewno Jakub Fontana w 1743 r. dobudował kruchtę przy tym kościele, w obecnym jego stanie niezachowaną ${ }^{79}$.

Jeszcze ok. 1730-1740 Franciszek Bieliński i jego żona Dorota Henrietta wystawili swojemu teściowi i ojcu, podskarbiemu wielkiemu koronnemu Janowi Jerzemu Przebendowskiemu, nagrobek w kościele Reformatów (il. 8), zaprojektowany przez Jakuba Fontanę, ozdobiony rzeźbą figuralną wykonaną zapewne przez Johanna Chrisostoma Redtlera (i1. 9), z którym architekt ów będzie później wielokrotnie współpracował ${ }^{80}$. Po $1755 \mathrm{r}$. tenże Jakub Fontana przekomponował nagrobek, dodając tumbę z drugą inskrypcja, poświęconą zmarłej Dorocie Henrietcie, oraz putta, z których jedno trzymało w rączce jej malowany na blasze portret, zaś drugie trzymało rączkę na sercu ${ }^{81}$. Mimo zachowanych w doskonałym stanie obu inskrypcji wymieniających fundatorów i świadczących o dwuetapowości powstania nagrobka ${ }^{82}$, w dotychczasowej literaturze obiekt ten błędnie uchodził za dzieło jednorodne, wystawione ok. 1729 r. wyłącznie przez córkę podskarbiego, bez jakichkolwiek podstaw przypisywane rzeźbiarzowi Jean-Josephe'owi Vinache'owi ${ }^{83}$. Dodatkowo Zbigniew Hornung uważał, że popiersie zostało wykonane jeszcze za życia Przebendowskiego na jego własne zamówienie, a następnie zaadaptowane do celów sepulkralnych. O tym, że był to podwójny nagrobek, autor zupełnie nie wspominał.

\footnotetext{
${ }^{73}$ Piotr BOHDZIEWICZ, „Kościół późnobarokowy w Karczewie”, Biuletyn Historii Sztuki, R. IX: 1947, s. 265 i n.

${ }^{74}$ BARTCZAKOWA, Jakub Fontana..., s. 35-36.

75 Jacek GAJEWSKI, „Sztuka w prymasowskim Łowiczu”, [w:] Łowicz. Dzieje miasta, red. Ryszard KOŁODZIEJCZYK, Warszawa 1986, s. 548.

${ }^{76}$ GUTTMEJER, „Kościół w Karczewie...”, s. 319-322.

${ }^{77}$ Karol GUTTMEJER, „Autorstwo i przekaz źródłowy, a interpretacja dzieła architektonicznego”, [w:] Architekt Budowniczy - Mistrz Murarski..., s. 71.

${ }^{78}$ Pod kierunkiem Carla Antonia Baya Fontana pracował przy budowie kościoła pijarów w Łowiczu; zob. Olgierd ZAGÓROWSKI, „Nieznany list Jakuba Fontany”, Biuletyn Historii Sztuki, R. XX: 1958, nr 3-4, s. 311.

${ }^{79}$ BARTCZAKOWA, Jakub Fontana ..., s. 36; GUTTMEJER, „Kościół w Karczewie...”, s. 326.

${ }^{80}$ Informację o twórcach nagrobka zawdzięczam Panu Prof. Jakubowi Sicie.

${ }^{81} \mathrm{Na}$ temat podwójnego nagrobka J.J. Przebendowskiego i D.H. Bielińskiej przygotowuję osobny artykuł.

${ }^{82}$ Treść podwójnej inskrypcji została wydrukowana w Pamiątkach Warszawy ks. Franciszka Ksawerego Kurowskiego, jednak wydanie rękopisu nie zostało skorygowane i inskrypcja zawiera poważne błędy i pominięcia fragmentów tekstu; zob. Franciszek Ksawery KUROWSKI, Pamiętniki miasta Warszawy, oprac. Eugeniusz SZWANKOWSKI, t. II, Warszawa 1949, s. 107-108.
} 


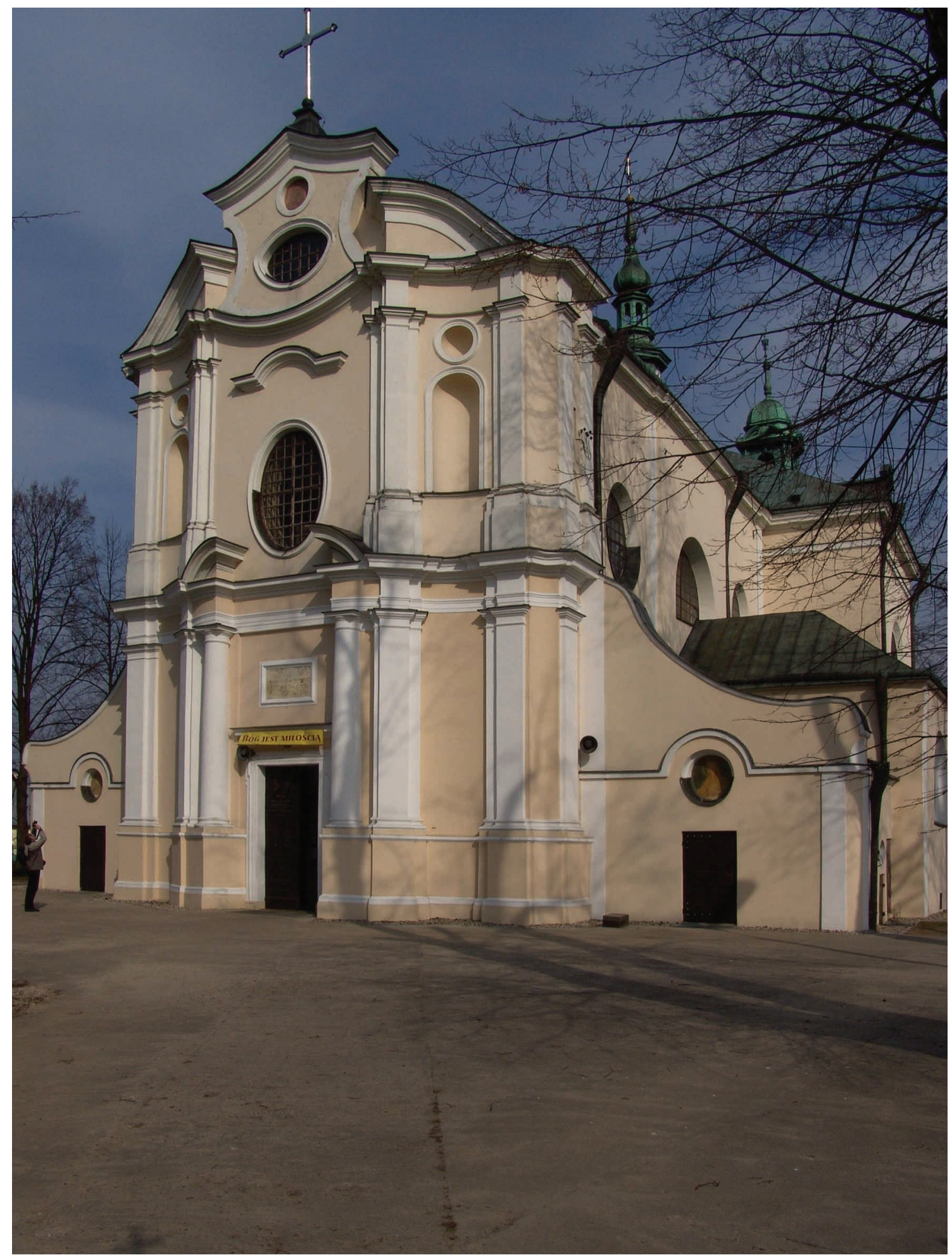

7. Carlo Antonio Bay (projekt), kościót parafialny w Karczewie, ok. 1728-1732, widok fasady. Fot. Monika Wyszomirska 


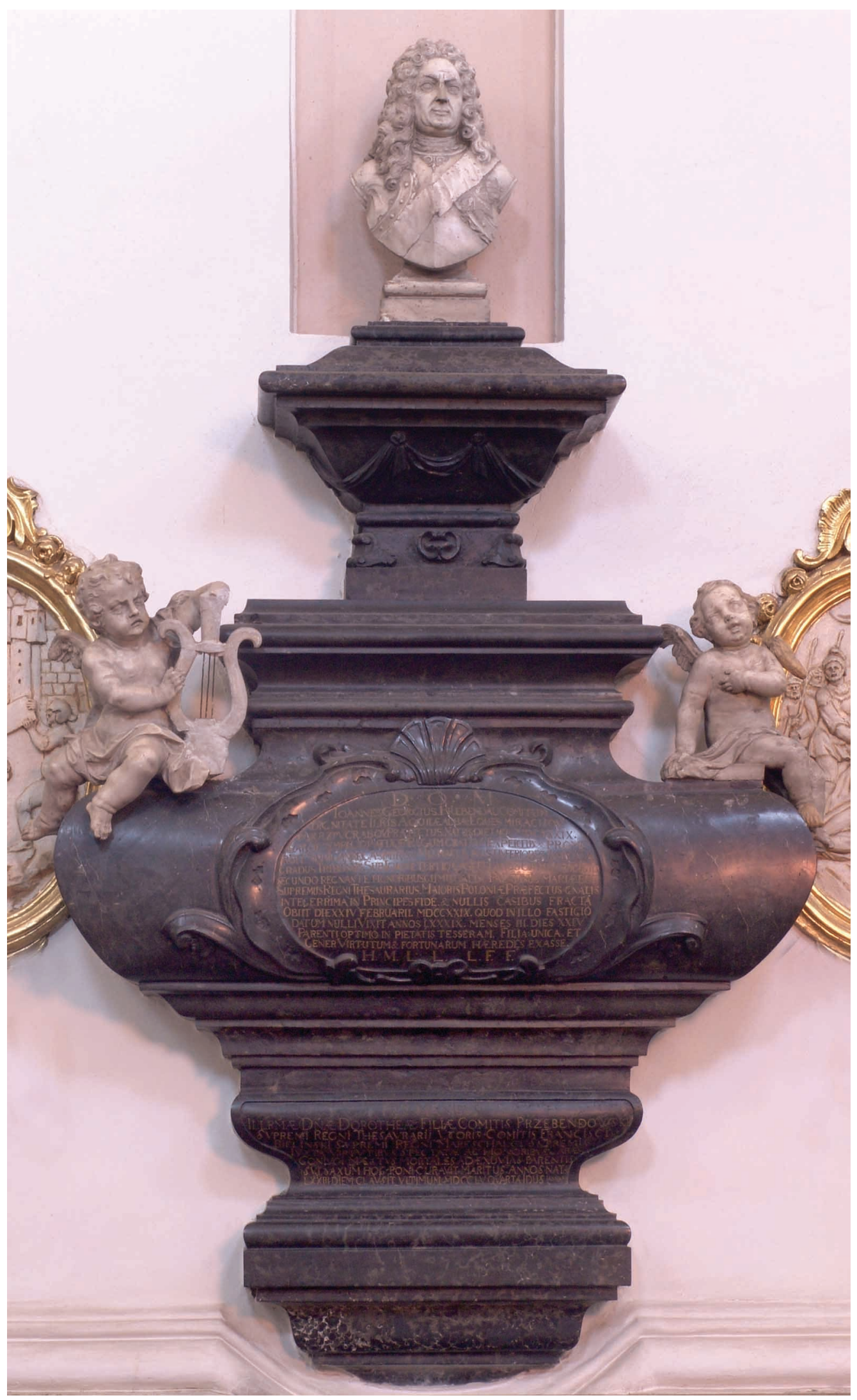

8. Jakub Fontana (projekt), Johann Chrisostom Redtler (dekoracja rzeźbiarska), nagrobek podskarbiego Jana Jerzego Przebendowskiego i jego córki Doroty Henrietty w kościele Reformatów w Warszawie, ok. 1730-1740, po 1755. Fot. Monika Wyszomirska 


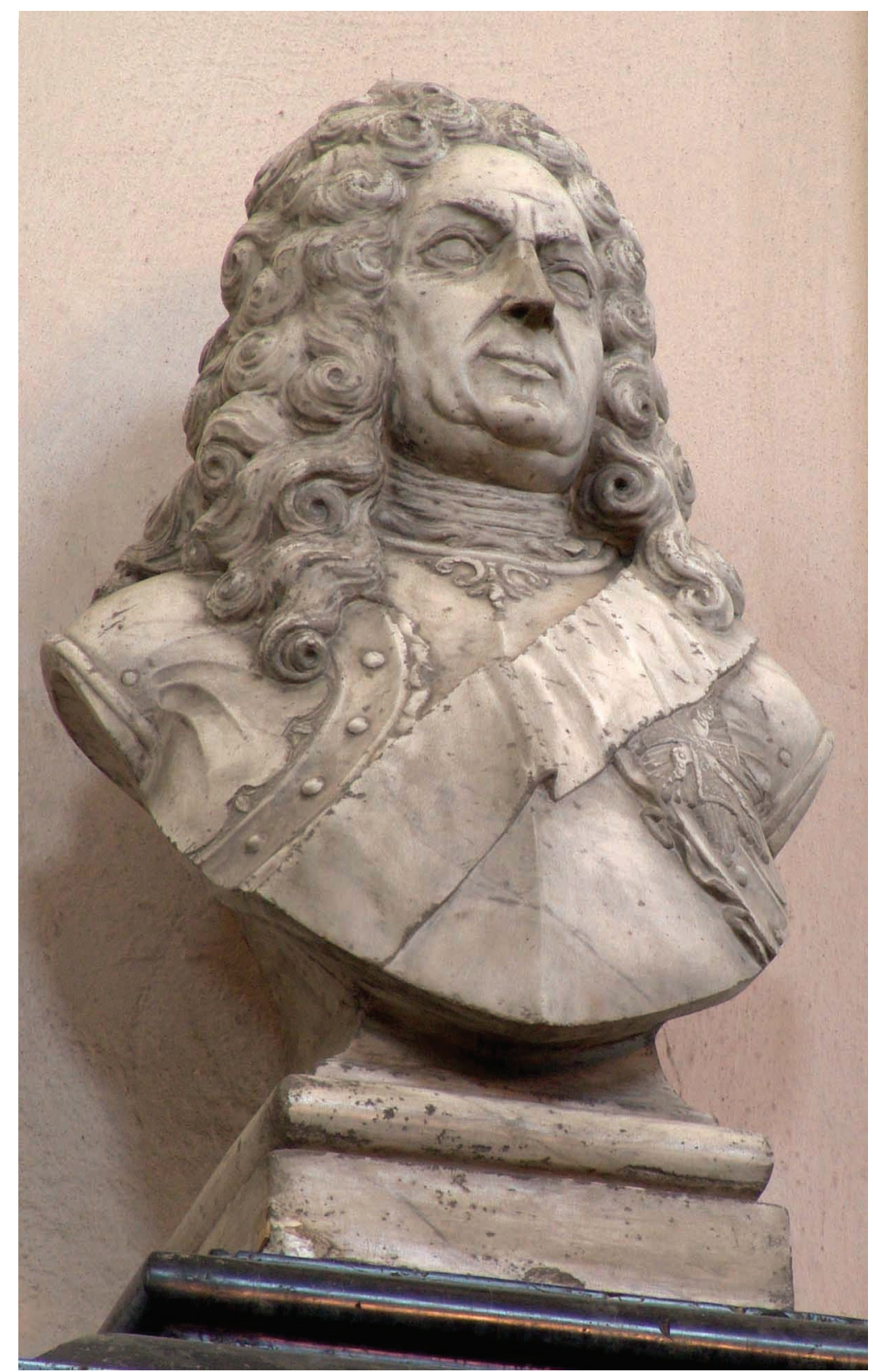

9. Jakub Fontana (projekt), Johann Chrisostom Redtler (dekoracja rzeźbiarska), nagrobek podskarbiego

Jana Jerzego Przebendowskiego w kościele Reformatów w Warszawie, ok. 1730-1740, popiersie Przebendowskiego.

Fot. Monika Wyszomirska

Dorota Henrietta, żona marszałka Franciszka Bielińskiego, zmarła 17 stycznia 1755 r. i kilka dni później została pochowana w grobowcu swojego ojca w warszawskim kościele Reformatów, gdzie 17 marca 1755 r. odbył się jej uroczysty pogrzeb. W końcu stycznia tegoż roku Jakub Fontana informował Eustachego Potockiego, cześnika koronnego, dla którego pracował przy „fabryce” pałacowej w Radzyniu, iż jest bardzo zajęty przygotowaniami do pogrzebu marszałkowej: ,,Jam srodze zabawny pogrzebem Imci P[ani] Marszałkowej Koronnej, który pro d. 17 martij determinowany, już od śmierci odpoczynku nie 
mam, mając wszelkie około preparatoriów staranie [...]"84. Kilka dni przed pogrzebem Jakub Fontana za pośrednictwem Grzegorza Marszałkowskiego, oficjalisty Potockiego, tłumaczył się Eustachemu, że „najmniejszego nie ma czasu pisać do niego, gdyż jest zatrudniony wielce apparencja pogrzebową" Doroty Bielińskiej ${ }^{85}$. Fontana niewątpliwie zajął się dekoracją kościoła oraz zaprojektował castrum doloris. Wprawdzie nie zachowały się żadne jego rysunki, jednak opis uroczystości i wygląd świątyni odnotował na swoich łamach „Kuryer Polski”86. Czytamy w nim, że „pogrzeb solenny Imci Pani Bielińskiej marszałkowej w. kor. w kościele OO Reformatów barzo piękną sztuki doryckiej J. Fontaniego kapitana wojsk koronnych odprawił się die 17 praes. Architekturą"87. Według tejże relacji pośrodku kościoła, na podwyższeniu okrytym karmazynowym suknem ustawiono epitafium z napisem dotyczącym zmarłej marszałkowej. Tuż obok uskrzydlona postać geniusza wyrażającego żal trzymała herb Bielińskich, powyżej epitafium umieszczono geniusza symbolizującego wieczność, który unosił portret Doroty Henrietty. Baldachim, również z karmazynowego sukna, był podtrzymywany przez osiem pozłacanych postaci geniuszów ustawionych na czterech postumentach, a na jego wierzchu pod złoconą koroną Fontana umieścił kartusze z herbami Bielińskich oraz Przebendowskich. Dookoła castrum doloris stało dwanaście srebrnych lichtarzy, być może na postumentach w kształcie zbliżonym do doryckich kolumn ${ }^{88}$.

Z myślą o zmarłej żonie w latach 1755-1760 marszałek wystawił i wyposażył zrujnowany m.in. po wichurze ${ }^{89}$ drewniany kościół Bernardynów p.w. Ofiarowania Najświętszej Marii Panny (obecnie p.w. Niepokalanego Poczęcia Najświętszej Marii Panny) w Górze (obecnie Góra Kalwaria) pod Warszawą. Projektantem kościoła również i tym razem był Jakub Fontana ${ }^{90}$.

Dzieje kompleksu bernardyńskiego w miasteczku słynącym z kilku kościołów i kaplic położonych w niewielkiej od siebie odległości sięga 1670 r. Wówczas to zostali sprowadzeni do Góry zakonnicy bernardyni, którym biskup poznański Stefan Wierzbowski, lokując ich przy pierwotnym drewnianym kościele parafialnym p.w. Wniebowzięcia NMP, powierzył opiekę nad stacjami Męki Pańskiej ${ }^{91}$. W 1673 r. tenże fundator sprowadził z Rzymu relikwie św. Waleriana.

Historia budowy świątyni i powstania jej wyposażenia w czasach Bielińskiego (nazwanego przez samych bernardynów drugim fundatorem) nie jest wystarczająco jasno omówiona w publikacjach. Pod datą 6 lutego 1755 r., a więc jeszcze przed uroczystym pogrzebem żony, zaplanowanym na 17 marca, Bieliński przesłał kustoszowi bernardynów w Górze memoriał, w którym przedstawiał warunki planowanej fundacji. W dokumencie zastrzegł sobie dwie codzienne msze wieczyste odprawiane za duszę zmarłej i o błogosławieństwo boże dla niego ${ }^{92}$. Aktu erekcyjnego i położenia kamienia węgielnego miano dokonać 19 lipca 1755 r. ${ }^{93}$ Funda-

\footnotetext{
${ }^{83}$ Zob. Zbigniew HORNUNG, „Wpływy drezdeńskie w rzeźbie polskiej XVIII w.”, Teka Komisji Historii Sztuki, t. III, Torun 1965, s. 228-230.

${ }^{84}$ J. Fontana do E. Potockiego, 30 I 1755, AGAD, Archiwum Publiczne Potockich (dalej: APP), sygn. 170, T. II, s. 665.

${ }^{85}$ G. Marszałkowski do E. Potockiego z Warszawy, 12 III 1755, AGAD, APP, sygn. 170, T. II, s. 122.

${ }^{86}$ BARTCZAKOWA, Jakub Fontana ..., s. 196.

${ }^{87}$ Kuryer Polski, 1755, nr 87.

${ }^{88}$ Ibid.; BARTCZAKOWA, Jakub Fontana..., s. 196.

${ }^{89}$ Małgorzata BORKOWSKA, Dzieje Góry Kalwarii, Kraków 2009, s. 168.

${ }^{90}$ BARTCZAKOWA, Jakub Fontana ..., s. 148-160.

${ }^{91}$ Por. Tadeusz LIPIŃSKI, „Miasto Góra Kalwaria. Opis historyczny”, Biblioteka Warszawska, 1842, t. IV, s. 556.

92 Archiwum Prowincji Bernardynów w Krakowie (dalej: APBern.), sygn. W-12, s. 141.

93 BARTCZAKOWA, Jakub Fontana ..., s. 149.
} 
cja, powstała dla uczczenia pamięci żony, niewątpliwe musiała być niezwykle ważna dla marszałka Bielińskiego, a zarazem prestiżowa także i dla Jakuba Fontany, który przez wdzięczność wobec swojego protektora podjął się budowy mimo licznych innych zleceń $^{94}$. O szacunku i oddaniu dla swego pryncypała najlepiej świadczył list architekta do Jana Klemensa Branickiego, w którym pisał, że ,jako temu Panu wielkie mam obligacje, tak nie z mniejszą rekognicją wysługiwać się powinienem"95.

Aldona Bartczakowa wyraziła przypuszczenie, że budowa zapewne nie zabrała architektowi zbyt wiele czasu z uwagi na skromną formę świątyni zarówno pod względem skali, jak i ubóstwa dekoracji ${ }^{96}$. Opierając się na źródłach nieznanych autorce biografii Jakuba Fontany, możemy jednak przyjrzeć się bardziej szczegółowo inicjatywie marszałka i pracom budowlanym prowadzonym w Górze Kalwarii w latach 1755-1760.

Interesujący jest fakt, że po upływie około trzech miesięcy od ustanowienia aktu erekcyjnego i rzekomego położenia kamienia węgielnego pod budowę kościoła, Bieliński zwrócił się do kanonika warszawskiego, księdza Krzysztofa Krakiera z Instytutu Księży Komunistów (Bartoszków), z prośbą o pobłogosławienie kamienia węgielnego z wyrytą w nim inskrypcją informująca o celach fundacji, zaaprobowaną przez władze zakonu, a także o przyłożenie ręki „do złożenia jego"97. Trudno sobie wyobrazić, aby uroczystość położenia kamienia węgielnego miała się odbyć bez poświęcenia fundacji przez osobę duchowną. Wydaje się więc, że do planowanej na 19 lipca 1755 r. uroczystości z jakichś powodów nie doszło, a data ta dotyczyła wyłącznie decyzji o fundacji budowli kościoła, umieszczonej w zapewne wcześniej przygotowanej inskrypcji. Od wiosny aż do jesieni 1755 r. marszałek (być może wskutek przeżyć po śmierci żony) stale uskarżał się na problemy zdrowotne, m.in. „ciężkość na piersi”, które uniemożliwiały mu opuszczanie pałacu i dlatego nie wziął udziału we wschowskiej radzie senatu ${ }^{98}$. Ponadto Jakub Fontana, który według Aldony Bartczakowej miał brać udział w uroczystości erekcyjnej 19 lipca $1755^{99}$, pozostawał wówczas z dala od Warszawy i Góry Kalwarii. Na podstawie kilku zachowanych relacji wiadomo, że architekt wracający z Białegostoku do Radzynia zachorował w drodze i dokładnie 19 lipca zatrzymał się na prawie dwa tygodnie w klasztorze Misjonarzy w Siemiatyczach ${ }^{100}$, nie mógł zatem być w tym czasie w Górze Kalwarii. $\mathrm{Z}$ całą pewnością odwiedził na krótko Górę dopiero we wrześniu 1755 r. ${ }^{101}$, być może w związku z planami organizacji przesuniętej w czasie uroczystości lub w związku z przygotowaniem do budowy.

Potwierdzenie moich wattpliwości oraz przypuszczeń co do zmiany daty erekcji przyniosła kwerenda w Archiwum Prowincji Bernardynów w Krakowie. Okazuje się, że dopiero 12 października 1755 r. kapituła prowincjalna zakonu obradująca w Radomiu zaaprobowała zamysł fundacji i warunki Franciszka Bielińskiego ${ }^{102}$, stąd następstwem tej

\footnotetext{
${ }^{94}$ Wspominał o tym Fontana w liście do J.K. Branickiego z 16 VI 1755, AGAD, ARK, sygn. VI/33, s. 13; zob. BARTCZAKOWA, Jakub Fontana..., s. 180.

95 J. Fontana do J.K. Branickiego z Warszawy, 16 VI 1755, AGAD, ARK, sygn. VI/33, s.13.

${ }^{96}$ BARTCZAKOWA, Jakub Fontana..., s. 149.

${ }^{97}$ F. Bieliński do ks. Krakiera z Otwocka, 28 X 1755, APB, AK, sygn. 6, s. 317.

${ }^{98}$ F. Bieliński do J. K. Branickiego z Warszawy 4 IV 1755 oraz F. Bieliński do J. K. Branickiego z Otwocka 23 IX 1755 , AGAD ARK, sygn. III/10, s. 45-46, s. 61.

99 BARTCZAKOWA, Jakub Fontana ..., s. 149.

${ }^{100}$ Ks. J. Hortyński do E. Potockiego z Siemiatycz, 24 VII 1755, AGAD, APP, sygn. 170 T. II, s. 281; A. Woźniacki do

E. Potockiego z Radzynia, 31 VII 1755, ibid., s. 276.

101 J. Fontana do E. Potockiego, 5 IX 1755 [b. m.], AGAD, APP, sygn. 170 T. II, s. 693.

102 APBern., sygn. W-12, s. 141.
} 


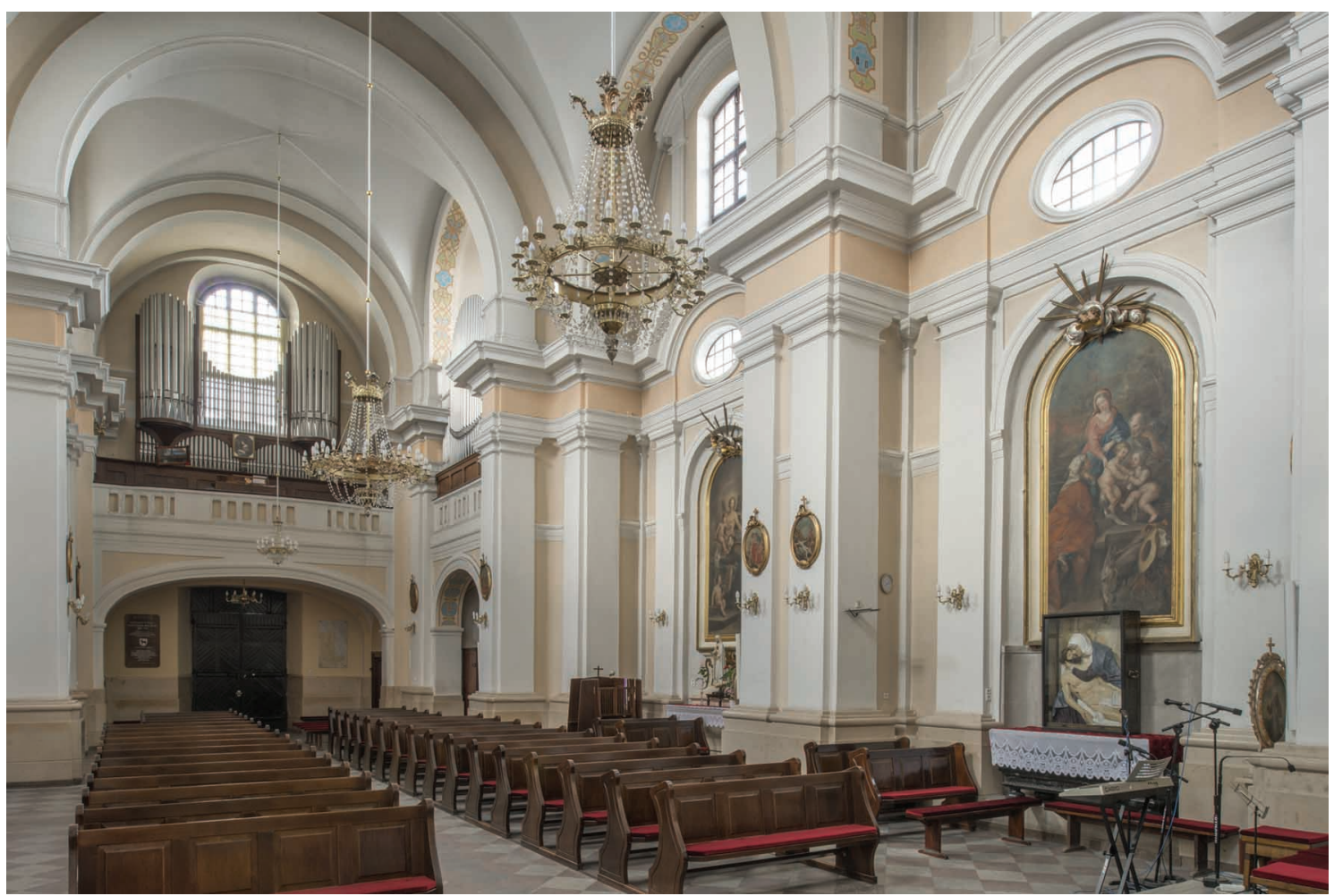

10. Jakub Fontana (projekt), kościót Bernardynów p.w. Ofiarowania Najświętszej Marii Panny (obecnie p.w. Niepokalanego Poczęcia Najświętszej Marii Panny) w Górze Kalwarii, 1755-1760, widok wnętrza. Fot. Piotr Jamski

decyzji był wzmiankowany list do księdza Krakiera z 28 października 1755 r. Położenie kamienia węgielnego, połączone $\mathrm{z}$ wmurowaniem na frontowej ścianie kościoła cynowej tablicy zawierającej epitafium poświęcone zmarłej żonie, miało miejsce dopiero 9 sierpnia 1756 r. W kamieniu węgielnym zamknięto relikwie św. Dionizego Areopagity, którego wspomnienie liturgiczne było obchodzone 17 stycznia, a więc dokładnie w rocznicę śmierci Doroty Henrietty ${ }^{103}$. Uroczystości poświęcenia przyszłej świątyni dokonał biskup poznański Teodor Czartoryski razem z wspominanym księdzem Krakierem.

W marcu 1756 r. Franciszek Bieliński protestował, kiedy ekonom położonych w województwie mazowieckim dóbr Czaplińskich nieprawnie zabrał dwanaście tarcic przeznaczonych „na potrzebę nowego kościoła WW OO Bernardynów w Górze"104. Chodzić musiało o belki czy też deski (zapewne do rusztowania), co wskazuje, że kościół pozostawał wówczas w fazie realizacji.

W dokumentach klasztornych zapisano, że Franciszek Bieliński wystawił „cum larga profusione expensarum optimae architectonicae elegantiae templum"105. Ściennofilarowa świątynia o wyrafinowanym, opiętym elegancką kratownicą podziałów wnętrzu (il. 10), z ołtarzami bocznymi we wnękach, pod chórem zakonnym mieściła kryptę św. Waleriana $\mathrm{z}$ ołtarzem tego męczennika widocznym $\mathrm{w}$ perspektywie $\mathrm{z}$ wnętrza prezbiterium przez obszerny otwór w mensie ołtarza głównego ${ }^{106}$. Relikwie tego świętego męczennika, zo-

\footnotetext{
103 Ibid., s. 124.

${ }^{104}$ F. Bieliński do NN [ekonoma dóbr Czaplińskich] z Warszawy, 17 III 1756, APB, AK, sygn. 6, s. 334.

105 APBern., sygn. W-12, s. 124.

106 Wzorem było tu rozwiązanie architekta Antoniego Solariego kaplicy św. Witalisa przy kościele Franciszkanów Konwentualnych w Warszawie; zob. Ryszard MĄCZYŃSKI, „Warszawa XVII i XVIII wieku jako centrum kultu relikwii
} 
stały, jak pamiętamy, sprowadzone do Góry jeszcze w XVII w. przez biskupa Wierzbowskiego i umieszczone wówczas w sarkofagu z czarnego marmuru. Sam projekt obudowy ołtarza relikwiarzowego, jak i całego wyposażenia opracował Jakub Fontana. Nie była dotąd znana informacja, iż w 1758 r. marszałek ofiarował tkaninę na wykonanie antepediów, ufundował wówczas także ornaty ${ }^{107}$.

17 marca 1759 r. Bieliński wystawił kolejny dokument, informujący o oczekiwaniu transportu drogą wodną spod Krakowa 150 łasztów wapna „na własną potrzebę fabryk moich tak w Górze mil pięć od Warszawy i tu w Warszawie w aktualnej robocie będących"108.

W 1760 r. klasztor w Górze Kalwarii, a częściowo także i nowo powstający kościół, strawił pożar. Według zapisu w księdze wydatków marszałka nadzór nad „fabryką” zniszczonych zabudowań po tej katastrofie sprawował w dalszym ciagu Jakub Fontana, otrzymując za to w 1760 r. kwartalne wynagrodzenie (liczone od św. Jana do św. Michała, a więc od 24 czerwca do 29 września) w kwocie 443 zł i 10 gr. ${ }^{109}$ Antoni Nowotny, stolarz otwocki, zgodnie z umową zawartą z Fontaną jako prowadzącym budowę, miał w maju 1760 r. ukończyć stalle w chórze kościelnym, w miejsce zatrudnianego poprzednio stolarza Johanna, który otrzymał „dymisję" ${ }^{110}$. W czerwcu tego roku ślusarzowi z Góry zapłacono 221 tynfów za bliżej nieokreśloną, ,robotę do kościoła"111. We wrześniu $1760 \mathrm{r}$. zakupiono półtora skrzyni szkła pochodzącego z huty w Osiecku z przeznaczeniem „na reparację okien w kościele WW OO. Bernardynów Górskich, które się spaliły jak klasztor gorzał"112. Szyby składające się z 434 elementów do sześciu okien wstawiał szklarz sprowadzony w tym celu z Warszawy ${ }^{113}$, chociaż jeszcze w czerwcu w podobne prace przy kościele był zaangażowany szklarz z Góry Kalwarii ${ }^{114}$. Wspomniany wcześniej stolarz otwocki Antoni Nowotny, w październiku 1760 r. wykonał stolarkę okienną i drzwiową w kościele oraz w klasztorze.

Na podstawie przytoczonych wyżej, nieznanych dotąd informacji widać, że kościół był budowany, a następnie wykańczany i wyposażany przez co najmniej pięć lat. Ponadto, jak wspomniano, kościół w roku 1759 został w jakiejś części dotknięty pożarem, co przyczyniło się do zahamowania niedokończonych jeszcze prac. W powstałym w połowie XIX w. dziele Ludwika Tripplina Góra Kalwaria, czyli Nowy Jeruzalem odnajdujemy informację, że „kościół z klasztorem dwukrotnie uległ pożarowi, a dzisiejsza piękna świątynia wraz z klasztorem i przyległymi zabudowaniami winna erekcję swoją Franciszkowi Bielińskiemu" 115 .

W strawionym pożarem budynku klasztornym Jakub Fontana zaprojektował m.in. drewniane schody (il. 11) oraz drzwi o rokokowym ornamencie, prowadzące do loży kolatorskiej marszałka Bielińskiego. Według Borkowskiej po odbudowie sfinansowanej ze zorganizowanej w tym celu kwesty, ,klasztor zyskał [jeszcze] piękniejszy

świętych", [w:] Historyczne centrum Warszawy. Urbanistyka. Architektura. Problemy konserwatorskie. Materiały z sesji naukowej Warszawa, 23-24 maja 1996, red. Bożena WIERZBICKA, Warszawa 1998, s. 80-99.

107 APK, AOM, sygn. 1209, s. 16, 25, 27.

108 APB, AK, sygn. 6, s. 447.

109 Ibid., s. 81.

${ }^{110}$ APK, AOM, sygn. 1207, s. 79.

${ }^{111}$ Ibid., s. 115.

112 APK, AOM, sygn. 1207, s. 143.

${ }^{113}$ Ibid., s. 133.

114 Ibid., s. 115.

${ }^{115}$ Ludwik TRIPPLIN, Góra Kalwaria, czyli Nowy Jeruzalem... Opis historyczno-statystyczny, Warszawa 1854, s. 12. 
wystrój"116, chociaż w porównaniu z kościołem była to budowa skromna, o raczej utylitarnym programie architektonicznym.

Mimo okresowych nieporozumień z zakonnikami, Bieliński płacił bernardynom za kapelanię w pałacu otwockim i hojnie obdarowywał zakonników. Kościół w Górze wybrał również dla siebie jako miejsce wiecznego spoczynku ${ }^{117}$. Na podstawie zachowanej kopii testamentu marszałka z 1765 r. wiadomo, że oprócz skromnej oprawy pogrzebu, kierując się tradycją rodową życzył sobie, aby jego spadkobiercy wystawili mu nagrobek, do którego został już wówczas u bernardynów zdeponowany medalion (lub płyta) z ,wyobrażeniem" fundatora, wykonany z brązu (,spiżu”) ${ }^{118}$. Prawdopodobnie bratankowie bezdzietnego dygnitarza nie uszanowali woli zmarłego, nic bowiem nie wiadomo o powstaniu jakiegokolwiek nagrobka. Nie wiemy również, czy w ewentualny projekt miał być zaangażowany Jakub Fontana.

Zupełnie nieznaną sprawą pozostaje kwestia finansowania budowy kościoła św. Floriana w Brwinowie, w dobrach należących wcześniej do ojca Doroty Henrietty Bielińskiej, Jana Jerzego Przebendowskiego. Na stronie internetowej parafii zasługa wzniesienia w 1760 r. nowego drewnianego dwuwieżowego kościoła na miejscu XVIIwiecznej świątyni została przypisana wyłącznie staraniom proboszcza księdza Baltazara Antoniego Tarkowskiego ${ }^{119}$. Z posiadanych przez nas źródeł wynika jednak, że obiekt sakralny mógł zostać wybudowany przede wszystkim dzięki przychylności i pieniądzom Franciszka Bielińskiego. Historia pozyskania źródeł finansowania tej inwestycji jest bardzo ciekawa. Otóż po śmierci niejakiego „Johana, konowała” z Miętnego w depozycie marszałka pozostała kwota 2000 florenów. Kwotę tę Bieliński postanowił przeznaczyć właśnie na budowę kościoła w Brwinowie, dokładając z własnej szkatuły jeszcze 3000 florenów ${ }^{120}$. Nie wiadomo jednak, czy projektantem i nadzorującym fabrykę kościoła był Jakub Fontana.

\section{Prace nad unowocześnieniem Warszawy}

Jak powszechnie wiadomo, „oczkiem w głowie” Franciszka Bielińskiego, swoistą idée fixe marszałka, była sprawa wybrukowania Warszawy, którą konsekwentnie realizował już od czasów nominacji na marszałkowstwo nadworne w 1732 r. i stale zabiegał o niezbędne fundusze na ten cel. Powołana w 1740 r. (jeszcze w okresie pełnienia przez niego funkcji marszałka nadwornego) Komisja Brukowa zajęła się poprawą stanu ulic warszawskich i higieną zanieczyszczonego miasta ${ }^{121}$. Komisja, której przewodniczącym marszałek, a skarbnikiem jego protegowany ławnik i wielokrotny burmistrz Nowej Warszawy Paweł Andrychowicz, zainaugurowała swoje obrady w końcu 1742 r., po czym została „zalimitowana” (odroczona) i wznowiła je wiosną 1743 r. w ratuszu warszawskim ${ }^{122}$. Co

\footnotetext{
116 BORKOWSKA, Dzieje Góry Kalwarii, s. 168.

${ }^{117}$ Informacja zamieszczona w pracy Borkowskiej, że obok Bielińskiego w podziemiach kościoła została pochowana jego żona, jest nieprawdziwa; por. BORKOWSKA, Dzieje Góry Kalwarii, s. 168.

118 Archiwum Państwowe w Bydgoszczy (dalej: APB), Archiwum Komierowskich z Komierowa (dalej: AK), sygn. 6, s. 728.

119 http://www.swflorian.com/historia2.html [dostęp 1 V 2019].

${ }^{120}$ APK, AOM, sygn. 1207, s. 63, 133.

121 Jacek STASZEWSKI, August III, Wrocław 1989, s. 235.

122 Archiwum Państwowe w Toruniu, Akta miasta Torunia, Katalog II, sygn. I-4798, k. 28 (gazeta pisana z Warszawy, 2 V 1743).
} 


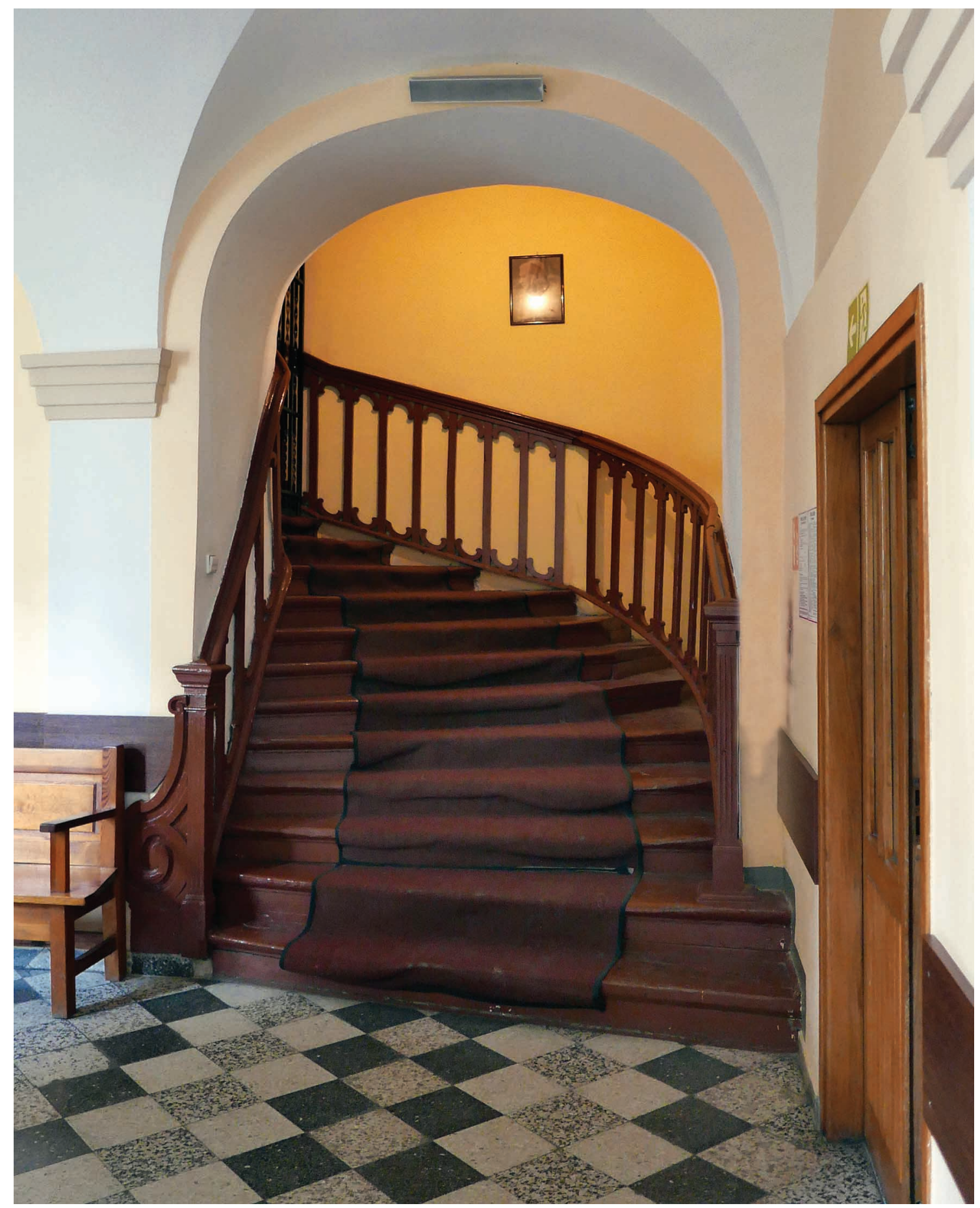

11. Jakub Fontana (projekt), drewniane schody prowadzace do loży kolatorskiej Franciszka Bielińskiego w klasztorze Bernardynów w Górze Kalwarii, ok. 1760. Fot. Monika Wyszomirska 
ciekawe, realizując ideę oczyszczenia i wybrukowania stolicy Bieliński brał pod uwagę nie tylko względy estetyczno-higieniczne ,zatopionej w błocie Warszawy z uszczerbkiem zdrowia przybywających i mieszkańców, z ochydą narodu, z obrzydliwością rezydencji JKMPMM”, ale dostrzegał także negatywny wpływ na drożyznę i ,niedostatek victualium", zwłaszcza w okresach obfitych opadów, kiedy drogi dojazdowe były niemal nieprzejezdne ${ }^{123}$.

Z inicjatywy Bielińskiego architekt Jakub Fontana dokonał pomiarów miasta, na których podstawie nałożono na mieszkańców podatek przeznaczony na oczyszczenie stoli$\mathrm{cy}^{124}$, tzw. łokciowe. Samo brukowanie na mocy decyzji rad senatu miało być finansowane ze skarbu państwa, a kwestia wypłaty pieniędzy na ten cel spoczywała na barkach podskarbiego wielkiego koronnego. Na marginesie należy dodać, że pomiary dokonane przez Fontanę, na których podstawie ustalono taksy od pałaców i placów, nie były chyba precyzyjne oraz wolne od błędów i może dlatego wywoływały często znaczne niezadowolenie właścicieli nieruchomości i posesji. Mieszczanie warszawscy zarzucali mu m.in. nieprawidłowo określoną liczbę pięter w domach, co miało mieć bezpośredni wpływ na wymiar podatku $^{125}$. Te i inne zastrzeżenia stały się również kolejną odsłoną zadrażnień między exkanclerzem i biskupem krakowskim Andrzejem Stanisławem Załuskim, który przypisywał sobie później palmę pierwszeństwa w stworzeniu projektu brukowania ${ }^{126}$, a marszałkiem Bielińskim. Biskup krakowski, który posiadał w Warszawie wiele nieruchomości, uskarżał się Bielińskiemu na olbrzymie wydatki przeznaczone na ten cel oraz na lekceważenie przez Jakuba Fontanę jego próśb w sprawie zajęcia się ulicą Senatorską, gdzie mieścił się jego pałac i, jak podkreślał, mieszkali pieczętarze (również kanclerz Jan Małachowski), których urzędowi należał się respekt ${ }^{127}$.

W związku z inicjatywą poprawy infrastruktury Warszawy marszałek w 1752 r. złożył u Johanna Georga Plerscha zamówienie na projekt pomnika św. Jana Nepomucena przy placu Trzech Krzyży (il. 12), który według wystawionego paszportu na kamień miał ,służyć ozdobie ulicy publicznej"128, a także upamiętniać ważny etap prac związanych z położeniem bruku i oczyszczeniem miasta ${ }^{129}$. Statua świętego była wykonana z piaskowca kunowskiego. Pośrednikiem w realizacji zamówienia u rzeźbiarza był oczywiście Jakub Fontana, który w styczniu 1752 r., na odwrocie zachowanego projektu pomnika ręki Plerscha poinformował o szczegółach zawartego kontraktu. Johann Georg Plersch, mając „komiss" od marszałka, zobowiązał się zakończyć pracę przed końcem sierpnia 1752 r. ${ }^{130}$ Fontana doprecyzował, że z przodu figury ma się znajdować nie ujęty „w abrysie” herb króla i Rzeczypospolitej, z tyłu zaś mały herb z insygniami władzy marszałkowskiej. Ponadto po obu przeciwległych stronach miała zostać umieszczona inskrypcja odnosząca się do osoby fundatora z wymownym określeniem Heros Bilinius dulce Decus Patriae ${ }^{131}$.

\footnotetext{
${ }^{123}$ F. Bieliński do J.B. Loupiego z Otwocka, 23 III 1745, AGAD, Arch. Kom., sygn. 9/9, s. 378.

124 Zob. np. BOBERSKI, „Splendor architekta...”, s. 35.

125 BARTCZAKOWA, Jakub Fontana..., s. 44.

${ }^{126}$ A.S. Załuski do F. Bielińskiego z Krakowa, 16 IV 1749, AGAD, Arch. Kom., sygn. 155/210, s. 1: Porzadek brukowy jako sadziłem potrzebny, tak mogę śmiele mówić, żem byt autorem i persvasorem JW. WMM Panu tego, któryś wziąt przed się.

127 Ibid., s. 2.

${ }^{128}$ Paszport na kamień, [III 1752], APB, AK, sygn. 6, s. 56.

129 Jakub SITO, „Rzeźba św. Jana Nepomucena - pamiątka po działalności Komisji Brukowej”, Spotkania z Zabytkami, 2016, nr 11-12, s. 36-39; id., Wielkie warsztaty..., s. 300.

${ }^{130}$ AGAD, Arch. Kom., sygn. 58/78, s. 375-376; SITO, op. cit., s. 300-301.

${ }^{131}$ Ibid.
} 


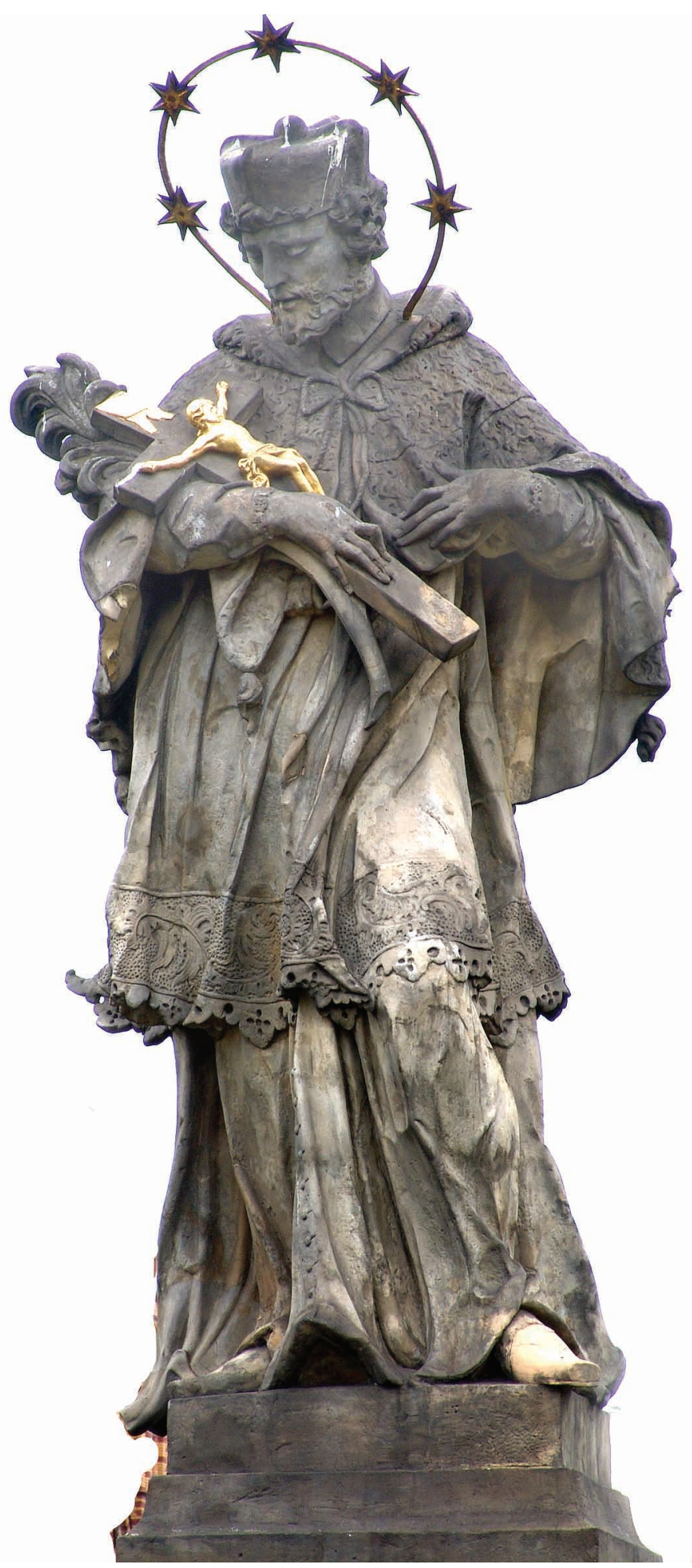

12. Jakub Fontana (projekt?), Johann Georg Plersch (wykonanie), pomnik św. Jana Nepoтucena na placu Trzech Krzyży w Warszawie, 1752. Fot. Jakub Sito 
Zachowały się również interesujące wzmianki o tym, że marszałek z racji sprawowanego urzędu wykazywał troskę o Zamek Królewski. Jednoznacznie wskazuje na to jego list do podskarbiego wielkiego koronnego Karola Józefa Sedlnickiego pisany w 1751 r., w którym wypominając adresatowi brak odpowiedzi ponownie interweniował w sprawie konserwacji Zamku, któremu groziło zawalenie się dachu, a także ,znaczne popsowanie tak kosztownych wewnętrznych ornamentów i w samych murach bliskie niebezpieczeństwo ruiny"132. Marszałek przypomniał Sedlnickiemu, że obowiązkiem podskarbich jest „konserwować fabryki Rz[eczpospo]1[i]tej, między którymi pryncypalna jest zamek warszawski, jako ordynaryjna Rezydencja Monarchów, Conclave Consiliorum et Officina Legum"133. Bieliński osobiście dokonał oglądu zniszczeń budowli i prosił również o stosowną ekspertyzę (ustną i pisemną) dwu architektów - Jakuba Fontanę oraz kierownika królewskiego „Bauamtu” Joachima Daniela Jaucha ${ }^{134}$. Do sprawy powrócił po kilku dniach, ponownie naprzykrzając się Sedlnickiemu, że bez naprawy dachu powiększa się ryzyko zniszczenia podczas zimy wewnętrznych ornamentów, zwracał też uwagę na konieczność naprawy kanału od strony pałacu Pod Blachą, który zagrażał murom zamkowym $^{135}$.

Stały zleceniobiorca, a w pewnym sensie i urzędnik dworski Bielińskiego, architekt Jakub Fontana przez ponad dwadzieścia lat współpracy z marszałkiem projektował również inne gmachy użyteczności publicznej, przeprowadzał regulacje i wytyczał kanały. W 1752 r. marszałek zezwolił na wytyczenie kanału melioracyjnego prowadzącego z pałacu barona Riaucoura położonego przy ulicy Miodowej, poprzez podwórze Dworu Gdańskiego, ulicę Podwale, Fosę Staromiejska, Mostową aż do Wisły, w celu oczyszczenia $\mathrm{z}$ wody deszczowej i ścieków piwnic pałacu właściciela i innych posesorów ${ }^{136}$. W jednym z listów z 1761 r. wspominany Paweł Andrychowicz informował Bielińskiego, że przekazał Jakubowi Fontanie 1000 tynfów tytułem ekspensy na wytyczenie kanału w pobliżu klasztoru wizytek. Wyrażał jednak zaniepokojenie, że „od kloak mają bydz okna do kanału zrobione, co by było przeciwko dawnej dyspozycji Jaśnie Wielmożnego WPana Dobrodzieja, ponieważ też i dekret komisji na to zszedł, aby były wszystkie okna zamurowane"137. Prosił więc marszałka o decyzję w tej kwestii. Można domniemywać, że architekt Jakub Fontana, autor projektu budowy kanału i nadzorca wykonania, sam podją decyzję o zachowaniu otworów. Najpewniej jednak marszałek przychylił się do próśb przełożonej sióstr wizytek, która życzyła sobie utrzymania okien. Na dzień przed wysłaniem listu przez Andrychowicza Bieliński napisał do matki Ludwiki Heleny Zborowskiej, że po konsultacji z architektami jest gotów wyrazić zgodę na to ustępstwo, pod warunkiem, że klasztorny ściek nie będzie szkodził kanałowi oraz przy zapewnieniu sióstr, że na wypadek jego zniszczenia zakonnice pokryją koszty natychmiastowej naprawy ${ }^{138}$. Na negatywne skutki przychylenia się do próśb wizytek nie trzeba było długo czekać i już

\footnotetext{
132 F. Bieliński do K.J. Sedlnickiego, 8 XI 1751, AGAD, Arch. Kom., sygn. 9/9, s. 746; por. Jerzy LILEYKO, Zamek warszawski. Rezydencja królewska i siedziba władz Rzeczypospolitej 1569-1763, Wrocław-Warszawa-Kraków-GdańskŁódź 1984, s. 274.

133 Ibid.

${ }^{134}$ F. Bieliński do J.D. Jaucha i J. Fontany, 8 XI 1751, AGAD, Arch. Kom., sygn. 9/9, s. 747.

${ }^{135}$ F. Bieliński do K. Sedlnickiego, 13 XI 1751, AGAD, Arch. Kom., sygn. 9/9, s. 796.

${ }^{136}$ Pozwolenie prowadzenia kanału przez ulice, 18 III 1752, AGAD, Arch. Kom., sygn. 9/9, s. 825-826.

${ }^{137}$ P. Andrychowicz do F. Bielińskiego z Warszawy, 22 VI 1761, AGAD, Arch. Kom., sygn. 155/210, s. 1-2 (Paweł Andrychowicz).

${ }^{138}$ F. Bieliński do M.L.H. Zborowskiej z Otwocka, 21 VI 1761, APB, AK, sygn. 6, s. 606-607.
} 
w miesiąc później szczegółową relację z prac nad kanałem składał Franciszkowi Bielińskiemu sam Jakub Fontana ${ }^{139}$.

\section{Bieliński-Fontana: wzajemne relacje}

Pora wreszcie na przyjrzenie się wzajemnym relacjom między marszałkiem Franciszkiem Bielińskim a architektem Jakubem Fontaną. Najwięcej wzmianek, które rzucają światło na powiązania marszałka-protektora oraz architekta zachowało się z połowy lat 40. i 50. XVIII w. W cytowanej wcześniej korespondencji do sędziego grodzkiego warszawskiego Szydłowskiego marszałek prezentował Fontanę jako człowieka rzetelnego, który swojej fortuny dorobił się uczciwym sposobem; ponadto powiadamiał, że architekt wyjechał właśnie „w ruskie kraje”, a wykorzystując jego nieobecność niewymieniony z nazwiska szwagier pozwał go, iuris pretextu non ratione iustitiae" ${ }^{140}$. Nie wiemy niestety, o którego szwagra mogło chodzić. Na podstawie testamentu architekta wiadomo, że oprócz siostry Magdaleny vel Marianny, żony Johanna Georga Plerscha, Fontana miał jeszcze dwie zamężne siostry - nieznane z imienia Pęczkowską oraz Deymową ${ }^{141}$. Bieliński tłumaczył, że nie wchodząc szerzej w tę znaną mu sprawę wstawiłby się za krzywdą każdego, nie mówiąc już, że powinien świadczyć wdzięczność osobie pozostającej aktualnie w jego usługach. Prosił zatem sędziego o odroczenie sprawy do czasu powrotu Jakuba Fontany ${ }^{142}$. Wkrótce w serdecznych słowach informował samego zainteresowanego, że „tu z strony naszej jest o interesie WMPana omnis sollicitudo”, ale nie wie, jak się sprawa potoczyła z powodu braku odpowiedzi na dwa listy od niejakiego pana Teslawa, (zapewne kapitana Johanna Teslaua, współpracownika Fontany, prowizora budowy i budowniczego, m.in. w rezydencji Czartoryskich w Puławach), zwykle nazbyt zajętego. List kończył się ,zapewnieniem o oddaniu ukłonu każdemu, któremuś WMPan życzył” i życzeniami szczęśliwego jak najszybszego powrotu ${ }^{143}$.

Nie był to jedyny dowód troski Bielińskiego o sprawy Jakuba Fontany. Innym razem, w 1748 r., marszałek interweniował w sprawie swojego architekta u Jana Rzyszewskiego, sekretarza poselstwa rosyjskiego w Warszawie. Chodziło o nakłonienie sekretarza do opuszczenia dworu (zapewne wynajętego od architekta), który zaczął już negocjacje w sprawie sprzedaży lub wynajmu budynku z pisarzem polnym koronnym Michałem Józefem Rzewuskim ${ }^{144}$. Być może był to dworek odziedziczony po ojcu, usytuowany naprzeciwko kościoła Bonifratrów.

Wyrazem zażyłych relacji między Jakubem Fontaną a Franciszkiem Bielińskim było uczestnictwo w 1748 r. marszałka i jego żony Doroty Henrietty w ceremonii chrztu córki architekta, Joanny Doroty Konstancji. Dziecko miało dwie pary rodziców chrzestnych: Franciszka Bielińskiego z Konstancją Flemingową, podskarbiną wielką litewską, oraz Jerzego Augusta Mniszcha, marszałka nadwornego, z Dorotą Henriettą Bielińską ${ }^{145}$.

\footnotetext{
${ }^{139}$ J. Fontana do F. Bielińskiego z Warszawy, 30 VII 1761, AGAD, Arch. Kom., sygn.. 58/78, s. 361-368.

${ }^{140}$ F. Bieliński do T. Szydłowskiego z Otwocka, [b. d.], [1745], AGAD, Arch. Kom., sygn. 9/9, s. 360.

${ }^{141}$ BARTCZAKOWA, Jakub Fontana..., s. 14. Testament opublikowany przez autorkę jako aneks VII (ibid., s. 315318).

${ }^{142}$ F. Bieliński do T. Szydłowskiego z Otwocka [b. d.], 1745, AGAD, Arch. Kom., sygn. 9/9, s. 360.

${ }^{143}$ F. Bieliński do J. Fontany [b. d.], [III 1745], AGAD, Arch. Kom., sygn. 9/9, s. 376.

${ }^{144}$ F. Bieliński do J. Rzyszewskiego, 12 VI 1748, AGAD, Arch. Kom., sygn. 9/9, s. 500.

${ }^{145}$ BARTCZAKOWA, Jakub Fontana ..., s. 42. Autorka, być może za Stanisławem Łozą, na którego się powoływała, podała błędną informację: podskarbiną wielką litewską była w 1748 r. Konstancja z Czartoryskich Flemmingowa, a nie
} 
Również Adam Kępski, sekretarz i zaufany Franciszka Bielińskiego, wyrażał się z dużym uznaniem o Jakubie Fontanie jako artyście europejskiej klasy i polecał go zaprzyjaźnionemu jezuicie księdzu Kiełłpszowi (Józefowi lub Michałowi), planującemu jakąś „fabrykę"146 , być może budowę kościoła w Iłłukszcie ${ }^{147}$. Kępski potwierdzał również, że Jakubowi Fontanie już wówczas nie dopisywało zdrowie, jako że często cierpiał na schorzenia nóg.

Ja wiadomo, lata 50. XVIII w. należały „,do okresu szczytowych osiagnięć Fontany”148, a w jego twórczości architektonicznej wyraźniej zarysowały się wówczas inspiracje francuskie (np. charakterystyczny motyw ryzalitu w kształcie serliany, obecny choćby w fasadzie pałacu przy Królewskiej). Można wręcz mówić o przyswojeniu w twórczości „lekcji paryskiej"149. Wiedzę o osiagnięciach architektury klasycyzmu Ludwika XIV, jak i o nowinkach okresu rokoka Jakub Fontana czerpał nie tylko z dostępnych wydawnictw, ale także z autopsji. Przypuszczam, że wpłynął na to powtórny pobyt architekta za granicą w roku 1747 - w Dreźnie, w Lunéville, a przede wszystkim w Paryżu, możliwy dzięki protekcji Franciszka Bielińskiego. Na podstawie zachowanego listu sekretarza marszałka, Adama Kępskiego, pisanego do Józefa Kępskiego, sędziego podkomorskiego wielickiego (prawdopodobnie jego brata ${ }^{150}$ ), dowiadujemy się, że Franciszek Bieliński, który na przełomie 1746 i 1747 r. udał się w podróż dyplomatyczną do Paryża i do Lunéville zabrał ze sobą Jakuba Fontanę, a pierwotnie obiecał udział w tej wyprawie także młodszemu bratu architekta, Janowi Kantemu, przyszłemu burgrabiemu zamku warszawskiego, który w 1752 r. był zatrudniony w kancelarii Kępskiego.

Franciszek Bieliński pozostawał również w przyjaznych relacjach z marszałkową wielką litewską Barbarą z Duninów Sanguszkową, przyszłą teściową jego bratanka Franciszka. Po śmierci jej męża Pawła Sanguszki sekretarz marszałka, Adam Kępski, na zlecenie Jakuba Fontany prowadził negocjacje z Johannem Georgiem Plerschem w sprawie kupna należących do niego placów i nieruchomości w Warszawie ${ }^{151}$.

Księga ekspensy marszałka obejmująca koniec 1759 r. i 1760 r. wymienia kapitana Jakuba Fontanę na liście urzędników dworskich, z kwartalnym wynagrodzeniem (premią?) w kwocie 250 złotych $^{152}$. Była to czwarta część ,zasług” pierwszoplanowej postaci dworu marszałka, jego sekretarza Adama Kępskiego, który otrzymywał najwyższą gratyfikację spośród wszystkich urzędników (1000 złp).

Według posiadanych przez nas źródeł współpraca Bielińskiego z Fontaną dobiegła końca około 1761-1762 r. W jednym z listów z połowy 1761 r. Fontana przyznawał, że spędził „najpiękniejszy wiek mój w pracach, umartwieniach i ustawicznej bojaźni niedostatku na starość, co się nie zgadza z opacznym mnie zawistnym mniemaniem, jakobym chciwie zbierał"153.

\footnotetext{
Izabela. Wskazują na to również kolejne imiona córki Fontany, otrzymane ewidentnie po matkach chrzestnych - Joanna Dorota Konstancja.

146 A. Kępski do ks. Kiełłpsza z Otwocka, 23 IX 1755, APB, Arch. Kom., sygn. 6, s. 374-375.

${ }^{147}$ Zob. Jerzy PASZENDA, „Kościół Jezuitów w Iłłukszcie”, Biuletyn Historii Sztuki, R. XL: 1978, nr 4, s. 287-300. Za powyższą sugestię bardzo dziękuję Panu Prof. Jakubowi Sicie.

148 BARTCZAKOWA, Jakub Fontana ..., s. 42.

149 GAJEWSKI, „Nagrobek Jana Tarły...”, s. 89-91; SITO, Wielkie warsztaty ..., s. 269.

${ }^{150}$ Adam Kępski nie ma nawet biogramu w Polskim słowniku biograficznym; wszelkie dane rodzinne uzyskujemy z jego nielicznych zachowanych listów oraz innych archiwaliów.

${ }^{151}$ A. Kępski do B. Sanguszkowej z Warszawy, 12 XII 1754, Archiwum Narodowe w Krakowie, Archiwum Sanguszków, teka 263, plik 3, s. 5-7.

152 APK, AOM, sygn. 1207, s. 181.

153 J. Fontana do F. Bielińskiego z Warszawy, 30 VII 1761, AGAD, Arch. Kom., sygn. 58/78, s. 367.
} 
Poinformował marszałka, że chociaż zdrowie mu nie dopisuje, jutro wybiera się do Radzynia, „,bo z warszawskich fabryk wyżywić się ledwo mogę"154. Prosił również swojego protektora, aby w sprawie kanału kontaktował się z Dominikiem Merlinim i jemu swoje „ordynował rozkazy”. List kończył się zapewnieniem, że „póki duch w ciele”, nie przestanie być uniżonym sługą Bielińskiego (,najniższym podnóżkiem”) ${ }^{155}$.

Zlecenia otrzymywane od Franciszka Bielińskiego nie były oczywiście jedynymi pracami architekta. Już na samym początku współpracy z Bielińskim trzydziestokilkuletni Fontana pracował dla pijarów przy gmachu Collegium Nobilium (1743) oraz przy kościele w Łowiczu (od 1740), w 1745 r. podjął się przebudowy fasady kościoła Św. Krzyża w Warszawie, a także budowy szpitala św. Rocha. Do końca wspólnej działalności dzielił czas między zamówienia realizowane dla marszałka a prace wykonywane dla innych magnatów, spośród których najważniejsze były chyba „fabryki” hetmana wielkiego koronnego Jana Klemensa Branickiego oraz cześnika koronnego Eustachego Potockiego.

Niniejsze rozważania prowadzą do wniosku, iż Jakub Fontana pełnił przy boku marszałka rolę swego rodzaju nadwornego architekta. Zdaje się to potwierdzać także wypłacana mu suma zasług kwartalnych (inna sprawa, że dość symboliczna). Na podstawie zachowanych źródeł można domniemywać, że Fontana cenił sobie protekcję marszałka, zadania, które powierzał mu Franciszek Bieliński, traktował z najwyższą powagą, a do niego samego żywił szacunek i jak sam wspominał ,wielkie miał obligacje”. Z kolei relacja Franciszka Bielińskiego wobec Fontany zdaje się wyczerpywać kryteria pojęcia mecenasa: nie tylko zlecał i finansował konkretne przedsięwzięcia artystyczne, mając zresztą wpływ na ich kształt, lecz także był rzecznikiem interesów swego protegowanego, zapewniał mu byt i okazywał względy jego rodzinie. Przypuszczam, że więzi zależności między Fontaną i Bielińskim nie były zbyt krępujące, skoro architekt równolegle podejmował się prowadzenia innych budów, często w bardzo odległych od siebie miejscowościach. Nie wiadomo natomiast, czy architekt przez cały czas służył swemu chlebodawcy z równym entuzjazmem, czy też po prostu sumiennie wypełniał zaciagnięte zobowiązania. Zbyt mało mamy wzmianek na ten temat i bezpośrednich świadectw obu bohaterów.

Nie była to chyba do końca relacja idealna, skoro uprzedzającą grzeczność Jakub Fontana okazywał równolegle innym magnatom, np. Eustachemu Potockiemu, cześnikowi koronnemu. Warszawski architekt nie tylko chętnie podejmował się szeregu zadań dla niego, ale również zamierzał pośredniczyć w zakupie wyposażenia czy nawet w ewentualnym nabyciu koronek po zmarłej marszałkowej Bielińskiej (!) ${ }^{156}$. Snuł także plany o nabyciu z jego pomocą jakiejś posiadłości ziemskiej, być może w sąsiedztwie jego dóbr radzyńskich ${ }^{157}$.

\footnotetext{
${ }^{154}$ Ibid.

155 Ibid., s. 268.

${ }^{156}$ J. Fontana do E. Potockiego, 17 II 1755, AGAD, APP, sygn. 170 T. II, s. 406.

157 J. Fontana do E. Potockiego, 14 VIII 1755, AGAD, APP, sygn. 170 T. II, s. 293-294.
} 


\section{Architect Jakub Fontana Employed by Marshal Franciszek Bieliński}

The paper is dedicated to the outstanding architect Jakub Fontana (1710-73), for about twenty years serving at the court of Marshal of the Court Franciszek Bieliński (1683-1766), later Grand Marshal of the Crown, a personage closely bonded with the Warsaw of the Saxon era. On the grounds of previously unknown archival sources, new facts are revealed that complete the so-far knowledge of the architect and shed additional light on the range, character, and chronology of his works for his patron. The beginnings of Franciszek Bieliński's acquaintance with Jakub's father Giuseppe Fontana are presented; the circumstances of two educational trips of the young architect to Paris, most likely partially sponsored by Bieliński, are discussed; these to be followed by the presentations of his main works on the church in Karczew, the residences in Otwock and Warsaw (in Królewska Street); the funerary ceremonies of Marshal's wife Dorota Henrietta née Przebendowski (castrum doloris
1755); the design and later re-composition of the tomb commemorating Jan Jerzy Przebendowski and Bieliński's wife; the raising of the church and convent in Góra Kalwaria (1755-60). Furthermore, what is discussed are a number of public projects executed by Jakub Fontana as the main architect of the Cobblestone Commission (until 1761) which the Marshal chaired as of 1742 (land surveys for marking out canals), as well as the vision of the royal castle; additionally, simultaneous works on establishing the Bielino jurisdiction (ca 1757) are signalled. In the final part of the article an attempt is made to present mutual relations between Jakub Fontana and Franciszek Bieliński, who being the patron did not only finance the projects, but also acted as an advocate of the architect's interests, showing much concern for his family. Jakub Fontana, in his turn, highly respected Bieliński and regarded the tasks commissioned by him with utmost attention. 